WSRC-RP--90-471

DE93 003312

HURRICANE HUGO AND ITS METEOROLOGICAL EFFECTS ON THE SAVANNAH RIVER SITE

M. J. Parker

Westinghouse Savannah River Company

Savannah River Site

Aiken, SC 29809

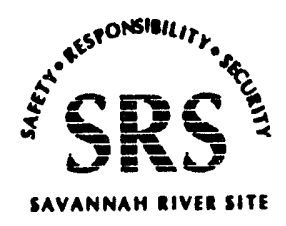

PREPARED FOR THE U.S. DEPARTMNENT OF ENERGY UNDER CONTRACT DE-AC09-89SR T3035 


\section{DISCLAIMER}

This report was prepared by Westinghouse Savannah River Company (WSRC) for the United States Department of Energy under Contract No. DE-AC09-89SR18035 and is an account of work performed under that contract. Neither the United States Department of Energy, nor WSRC, nor any of their employees makes any warranty, expressed or implied, or assumes any legal liability or responsibility for the accuracy, completeness, or usefulness, of any information, apparatus, or product or process disclosed herein or represents that its use will not infringe privately owned rights. Rèference heicin to any specific commercial product, process, or service by trademark., name, manufacturer or otherwise does not necessarily constitute or imply endorsement, recommendation, or favoring of same by WSRC or by the United States Government or any agency thereof. The views and opinions of the authors expressed herein do not necessarily state or reflect those of the United States Government or any agency thereof.

Available to DOE and DOE contractors from the Office of Scientific and Technical Information, P.O. Box 62, Oak Ridge, TN 37831; prices available from (615) 576-8401, FTS 626-8401.

Available to the public from the National Technical Information Service, U.S. Department of Commerce, 5285 Port Royal Rd., Springfield, VA 22161. 
WSRC-RP-90-471

Retention: Lifetime

Key Words

Storm track

Forecast

Wind speed

Rainfall

Wind damage potential

HURRICANE HUGO AND ITS METEOROLOGICAL EFFECTS ON THE SAVANNAH RIVER SITE

M. J. Parker

Publication Date: March 26, 1990

Westinghouse Savannah River Company

Savannah River Site

Aiken, SC 29809

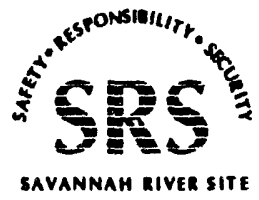

PREPARED FOR THE U.S. DEPARTMENT OF ENERGY UNDER CONTRACT DE-AC09-89SR18035 


\section{CONTENTS}

EXECUTIVE SUMMARY ..............................................................................................

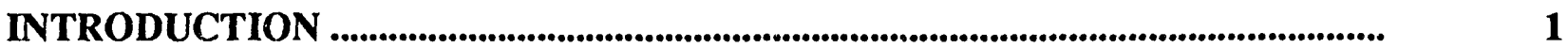

LIFE HISTORY OF HUGO ..........................................................................................

SRS METEOROLOGICAL STAFF ACTIVITIES .....................................................

OBSERVED WEATHER ..............................................................................................

POTENTIAL WIND DAMAGE ASSESSMENT FOR SRS ........................................ 6

REFERENCES ............................................................................................................................

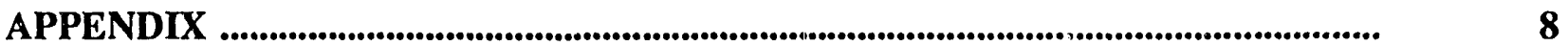


1 The Track of Hurricane Hugo (sustained winds > $74 \mathrm{mph}$ ) .................................... 10

2 Infrared Image of Hugo's Position (lower right) at 6 a.m. on September 15, 1989 (maximum sustaied winds $120 \mathrm{mph}$ )

3 Infrared Image of Hugo (left, maximum sustained winds $105 \mathrm{mph}$ ) and Tropical Storm Iris (right, sustained winds $<75 \mathrm{mph}$ ) at 9 a.m. on September 19, 1989.

4 Infrared Image of Hugo as the Eye Approaches Charleston, SC (maximum sustained winds $135 \mathrm{mph}$ ) at 10 p.m. on September 22, 1989

5 Infrared Image of Hugo as the Western Edge of the Eye Reaches Charleston, SC (maximum sustained winds $135 \mathrm{mph}$ ) at 11 p.m. on September, 221989.

6 Infrared Image of Hugo with the Eye Directly Over Charleston, SC (maximum sustained winds $135 \mathrm{mph}$ ) at 12 a.m. on September 23, 1989

7 Infrared Image of Hugo with the Eye Still Visible Well Inland at 1 a.m. on September 23, 1989

8 Infrared Image of Hugo without a Discernable Eye (maximum sustained winds $80 \mathrm{mph}$ ) at 4 a.m. on September 23, 1989.

9 Radar Image of Hugo Showing the Eye Offshore with Surrounding Spiral Rainbands at 10 p.m. on September 221989

10 Radar Image of Hugo as the Fierce Weather of the Eyewall Hits Charleston, SC at 11 p.m. on September 22, 1989

11 Radar Image of Hugo as the Eye Passes Over Charleston, SC at 12 a.m. on September 23, 1989 (Note the strong bands of showers over north central Georgia and extreme northeast South Carolina.)

12 Radar Image of Hugo After the Eye Has Moved Inland at 1 a.m. on September 23, 1989

13 Radar Image of Hugo as the Eye Passes Near Sumter, SC at 2 a.m. on September, 231989 
14 Radar Image of Hugo with the Eye Near Sumter, SC at 3 a.m. on September 23, 1989 (Note the strong band of showers in north central Georgia.)

15 Radar Image of Hugo with the Eye to the Southeast of Charlotte, NC at 4 a.m. on September 23, 1989

16 Time Series of 15-Minute Averages of the Spatially Averaged Wind Speed from Eight 60-m Towers at SRS (The wind affected by Hugo is demarcated.)

17 Time Series of 15-Minute Averages of Wind Speed from the C-Area 60-m Tower at SRS (The wind affected by Hugo is demarcated.)

18 Time Series of Wind Gusts from the C-Area 60-m Tower at SRS (The wind affected by Hugo is demarcated.)

19 Time Series of 15-Minute Averages of the Spatially Averaged Wind Direction from Eight $60-\mathrm{m}$ Towers at SRS (The wind affected by Hugo is demarcated.)

20 Time Series of 15-Minute Averages of the Spatially Averaged Standard Deviation of Wind Elevation Angles (sigma-E) (The wind affected by Hugo is demarcated.)

21 Pressure Trace from Microbarograph Located in Building 773-A (The lowest pressure recorded was $986 \mathrm{mb}$ at $3 \mathrm{a.m}$. on September 23, 1989.)

22 Location of Meteorological Towers and Rain Gauges at SRS 
1 Historical Weather Data for SRS and Surrounding Region ................................ 3

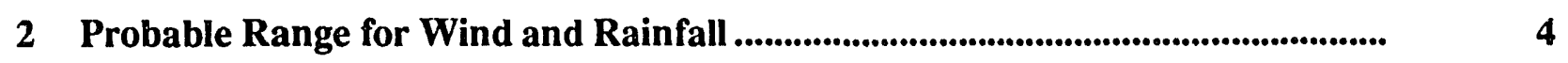

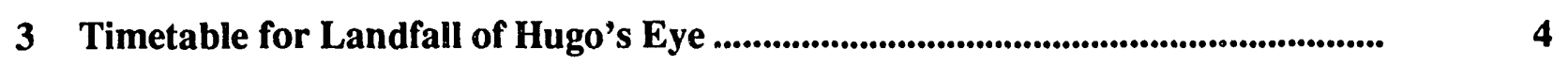

4 Updated Probable Ranges from Wind and Rainfall ............................................ 5

5 Total Rainfall Amounts During Hurricane Hugo (inches) ................................... 6

6 Potential Wind Damage Assessment from Hugo .......................................... 7 


\title{
HURRICANE HUGO AND ITS METEOROLOGICAL EFFECTS ON THE SAVANNAH RIVER SITE
}

\author{
By M. J. Parker \\ Westinghouse Savannah River Company \\ Savannah River Site \\ Aiken, SC 29808
}

\section{EXECUTIVE SUMMARY}

During its nine day existence, Hurricane Hugo tracked thousands of miles, caused millions of dollars in property damage, and took many lives. Puerto Rico, Guadeloupe, the Virgin Islands, and South Carolina took the brunt of the storm. The staff of meteorologists of the Environmental Technology Section (ETS) provided briefings and forecasts to assist Savannah River Site management in developing appopriate site-wide protective action plans. "Loops" created from infrared satellite imagery provided the most useful forecasting tool. Single-site, composite radar imagery and wind measurements from the nine $200 \mathrm{~m}$ towers provided real-time monitoring of the effects of Hugo at SRS. A peak wind gust of $64.9 \mathrm{mph}$ and up to 5.05 inches of precipitation were recorded at SRS. An assessment of the potential for wind damage to selected SRS facilities, had Hugo passed over SRS, showed that little structural damage would have occurred with proper pre-storm preparation.

\section{INTRODUCTION}

In the Southeast, destruction in the aftermath of Hurricane Hugo was widespread. A swath of damage extended from Charleston, SC, where the "eye" made landfall, through the midlands of South Carolina, to the foothills of North Carolina. Property damage in the United States from Hugo was approximately $\$ 7$ billion. 1 Fortunately, the loss of life was small because of extensive evacuation of coastal areas. SRS escaped major damage from Hugo, although heavy rain and high winds were observed. The purpose of this report is to discuss the life history of Hugo, the activities of the staff of meteorologists at SRS during Hugo's existence, the observed weather at SRS, and the potential for wind damage to selected facilities from a Hugo-type hurricane at SRS.

\section{LIFE HISTORY OF HUGO}

On September 11,1989, at 2 a.m. (all times are Eastern Daylight Time (EDT)), a tropical depression had formed in the Atlantic Ocean about 450 miles off the west coast of Africa. By 6 p.m., this storm was named "Hugo" as winds had increased to tropical storm strength (i.e., maximum sustained winds in the $38-73 \mathrm{mph}$ range). Hugo attained hurricane status (i.e., maximum sustained winds exceeding $74 \mathrm{mph}$ ) at 6 p.m. on September 13 and was located approximately 1000 miles east of Barbados (Figure 1). At 6 p.m. on September 15, when the eye of Hugo was located 300 miles east of Barbados, the maximum storm intensity was observed. The central pressure had dropped to $918 \mathrm{mb}$ and sustained winds were $150 \mathrm{mph}$ with gusts up to $173 \mathrm{mph}$ as Hugo churned to the west at $15 \mathrm{mph}$. At this time Hugo exhibited many of the same characteristics of Hurricane Gabrielle, which had been located about five degrees to the north only 10 days earlier. However, Gabrielle had turned harmlessly out into the north Atlantic. Hugo's position, in contrast, posed a much greater threat to land areas in the Carribean Sea.

Hugo tracked through the Leeward Islands directly over Guadeloupe, passed to the west of the Virgin Islands on September 17, and struck the northeastern tip of Puerto Rico on the following day. As Hugo crossed these islands, its forward speed decreased from approximately $12 \mathrm{mph}$ to 
less than $10 \mathrm{mph}$, which increased the islands' exposure to hurricane force winds. The extensive damage which occurred over these islands gave a strong warning that Hugo was a highly dangerous storm and was capable of producing massive damage and fatalities.

Hugo weakened and tracked to the northwest after passing over Puerto Rico. Maximum sustained winds decreased to approximately $105 \mathrm{mph}$ as the storm passed to the east of the Bahama Islands. This decrease in strength probably had two causes. The first cause was the passage over a land area (Puerto Rico), which reduced the available moisture that is used as the main energy source of the hurricane. The second cause was the proximity of another tropical storm, Iris, which had formed to the east of Hugo. The rarely observed Fujiwara effect, ${ }^{2}$ in which two tropical storms rotate relative to each other, apparently prevented Hugo from rapidly regaining strength by limiting its rotation. As Hugo continued to track northwestward, there was much concern that a turn to the west would put the Bahama Islands and Florida in the pathway. Concerns were also growing in the Southeast because Hugo was nearing the U.S. mainland. To a lesser degree, Iris was also of concern as it continued to intensify.

The general synoptic scenario on September 20-21 showed a large area of high pressure off the coast of New England and a decaying stationary front located just off the Southeast coast. This high pressure pattern provided steering currents which encouraged a northwesterly track toward the southeast coastline for Hugo. The decaying stationary front was becoming rather weak and did not alter Hugo's path.

At 9 a.m. on the September 21, Hugo was centered near 240 miles east of Cape Kennedy, and maximum sustained winds were $110 \mathrm{mph}$. The forward speed was to the northwest at $17 \mathrm{mph}$. The area between Savannah, Ga. and Charleston, SC appeared to be the most likely target for landfall according to the National Hurricane Center (NHC). Iris weakened to a tropical depression at 12 p.m. on September 21. By 6 p.m., Hugo had strengthened (sustained winds now at 135 $\mathrm{mph}$ ) and had increased in forward speed to the northwest at $20 \mathrm{mph}$. Hugo had increased from a Category 2 to a Category 4 hurricane (Appendix A) in the course of one day, and the time of the highest probability for landfall was at the time of high tide. The potential for serious damage along the South Carolina coast was very high.

Landfall of the eye of Hugo occurred between 11 p.m. and 1 a.m. on the 22nd of September. The maximum sustained winds were $135 \mathrm{mph}$ and the central pressure had dropped to $934 \mathrm{mb}$, the lowest point since before striking Puerto Rico. Fortunately, the loss of life was not as high as possible due to extensive evacuation of the Charleston area. Property damage was excessive in Charleston and in the nearby coastal area, especially toward Myrtle Beach.

Hugo was downgraded to tropical storm status at 6 a.m. on September 22 when the poorly defined eye was located in the vicinity of Rock Hill, SC.

\section{SRS METEOROLOGICAL STAFF ACTIVITIES}

Soon after Hugo became a hurricane, ETS meteorologists (R. P. Addis, C. H. Hunter, R. J. Kurzeja, M. J. Parker, A. H. Weber) at the SRS began monitoring the storm track and development in the Weather Center Analysis Laboratory (WCAL) located in building 773-A. The equipment capability of the WCAL is geared toward emergency response and includes a National Weather Service (NWS) Automated Field Operation System (AFOS) work station, a real-time radar feed (for precipitation detection) from the Augusta (AGS) office of the National Weather Service, a work station to WSI Corporation used mainly for downloading infrared satellite and composite radar imagery, and a display of meteorological data from nine 200 - $\mathrm{ft}$ onsite towers. Satellite "loops" (repeated series of satellite or radar images exhibited sequentially) showed Hugo's 
development and progression. In its early stages of existence, the proximity of Hugo posed a small threat to the Southeast, but as time passed, Hugo appeared to be headed for a probable U.S. mainland landfall. Each update on position, intensity, and landfall probabilities issued by the National Hurricane Center (NHC) was evaluated for the relevant effects of Hugo on SRS. The primary objective of the staff was to provide briefings of weather information updates and forecasts for WSRC and DOE/SR management.

- The first formal briefing of the WSRC and DOE/SR management staffs by ETS meteorologists was conducted at approximately 3 p.m. on Wednesday, September 20. The latest sustained wind speeds, position, and landfall probabilities provided by the NHC were discussed as well as climatological data concerning regional hurricane and tornado occurrences and extreme wind and rainfall. (At 3 pm, Hugo was located 350 miles east of Grand Bahama Island.) Historical SRS data for previous hurricanes (i.e., Gracie, 1959) were also discussed. These data are summarized in Table 1.

\section{Table 1. Historical Weather Data for SRS and Surrounding Region}

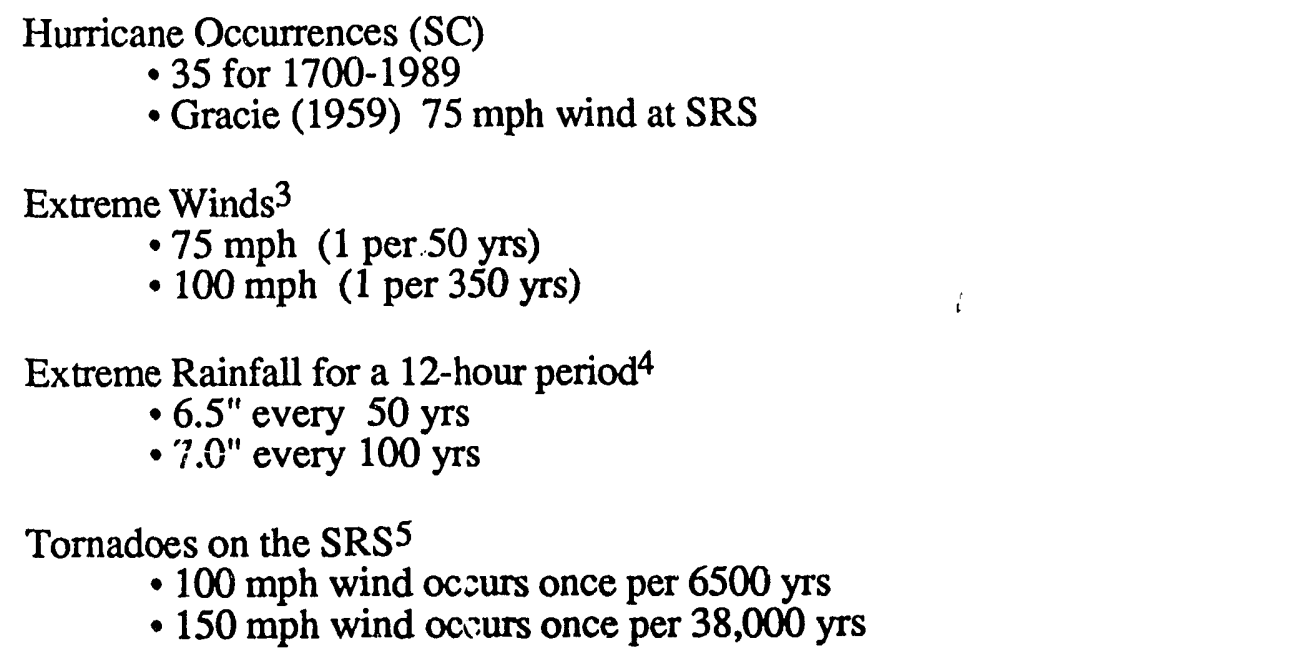

By 9 a.m. Thursday, September 21, Hugo had moved to about 350 miles southeast of Savannah (maximum sustained winds, $110 \mathrm{mph}$; forward speed, $17 \mathrm{mph}$ ). A second, more extensive briefing of the WSRC and DOE/SR management staffs was held at midday to discuss the most recent observations and forecast information. Table 2 shows the probable ranges for wind and rainfall for SRS formulated by ETS meteorologists. These ranges were derived from historical data from previous regional hurricane landfalls and were based on Hugo making landfall over Charleston, SC. Table 3 shows a timetable for landfall of the eye of Hugo. At this time, the NHC had issued a hurricane warning from Fernandina Beach, FL to Cape Lookout, NC, with the highest probable landfall pinpointed at Charleston, SC. 
Table 2. Probable Ranges for Wind and Rainfall (as given in a briefing to the General Staff at 12 noon on September 21, 1989)

\begin{tabular}{rcccc}
\hline Sept. 22 & $\begin{array}{l}\text { Probable Wind } \\
\text { Speed/Gust (mph) }\end{array}$ & $\begin{array}{l}\text { Worst Case Wind } \\
\text { Speed/Gust }\end{array}$ & $\begin{array}{l}\text { Probable } \\
\text { Rainfall } \\
\text { inches }\end{array}$ & $\begin{array}{l}\text { Worst Case } \\
\text { Rainfall } \\
\text { inches }\end{array}$ \\
\hline & & & & 2 \\
6 a.m. & $20 / 25$ & $25 / 30$ & 2 & 4 \\
9 a.m. & $30 / 40$ & $40 / 50$ & 3 & 7 \\
12 p.m. & $45 / 55$ & $55 / 65$ & 4 & 10 \\
3 p.m. & $40 / 50$ & $50 / 60$ & 6 & 12 \\
6 p.m. & $30 / 40$ & $40 / 50$ & 8 & \\
\hline
\end{tabular}

Table 3. Timetable for Landfall of Hugo's Eye (as given in a briefing of the General Staff at 12 noon on September 21, 1989)

\begin{tabular}{rr}
\hline $\begin{array}{c}\text { Time (starting } \\
\text { on Sept. 21) }\end{array}$ & Miles from the Coastline \\
& \\
\hline & \\
9 a.m. & 350 \\
12 p.m. & 300 \\
3 p.m. & 250 \\
6 p.m. & 200 \\
9 p.m. & 150 \\
12 a.m. & 100 \\
3 a.m. & 50 \\
6 a.m. & 0 \\
\hline
\end{tabular}

By 3 p.m. Thursday, September 21, Hugo increased dramatically in strength (maximum sustained winds, $125 \mathrm{mph}$ ) and forward speed $(20 \mathrm{mph})$. An updated briefing was given at $5 \mathrm{p} . \mathrm{m}$. to the WSRC and DOE/SR management staffs. Table 4 shows the new probable ranges for wind and rainfall for SRS, which were still based on landfall of the eye at Charleston, SC, now predicted for 3 a.m. Based on the latest computerized model simulations, the NHC had changed their prediction for landfall to Myrtle Beach, SC. However, the ETS meteorologists continued to predict landfall at Charleston, SC. The rationale for the ETS forecast evolved around the satellite loops (see next section) which indicated that Hugo was gaining forward momentum as it strengthened and headed toward Charleston, SC, and therefore, a turn toward the north appeared unlikely despite the model forecasts. In addition, there was no significant weather system likely to influence the upper-level steering currents and thus, alter Hugo's path. The ETS forecast prompted emergency management to call for a limited activation of the SRS Emergency Management Technical Support Center (TSC). ETS meteorologists continued to monitor radar, satellite, and NHC information in the WCAL and provided the TSC with updates until 6 a.m. when the threat from Hugo had passed. 
Table 4. Updated Probable Ranges for Wind and Rainfall (as given in a briefing of the General Staff at 5 p.m. September 21, 1989)

$\begin{array}{lllll}\text { Sept. } 22 & \begin{array}{l}\text { Probable Wind } \\ \text { Speed/Gust }(\mathbf{m p h})\end{array} & \begin{array}{l}\text { Worst Case Wind } \\ \text { Speed/Gust (mph) }\end{array} & \begin{array}{l}\text { Probable } \\ \text { Rainfall Worst Case } \\ \text { inches }\end{array}\end{array}$

\begin{tabular}{rrrrr}
\hline 3 a.m. & $30 / 40$ & $40 / 50$ & 2 & 2 \\
6 a.m. & $30 / 40$ & $50 / 60$ & 3 & 4 \\
9 a.m. & $30 / 40$ & $60 / 75$ & 4 & 7 \\
12 p.m. & $25 / 35$ & $50 / 60$ & 6 & 10 \\
3 p.m. & $20 / 30$ & $40 / 50$ & 8 & 12 \\
6 p.m. & $20 / 30$ & $25 / 30$ & &
\end{tabular}

Predicted Landfall of the Eye of Hugo: 3 a.m.

\section{OBSERVED WEATHER}

The most practical early monitoring of Hugo was done through the use of infrared satellite imagery. The track and development are readily observable in remote areas where few, if any meteorological measurements are taken. As Hugo approached the Southeast, continuous singlesite (AGS) and composite radar images were used to track the path of the eye and spiral rainbands. Wind speed and direction at SRS were measured by nine 200 - $\mathrm{ft}$ onsite meteorological monitoring towers. Barometric pressure was measured in Building 773-A, and precipitation was measured at eight sites on the SRS. The following is a summary of the data gathered by ETS concerning Hugo.

Figure 2 shows Hugo's position at 6 a.m. on September 15, 1989. At this time, maximum sustained winds were $120 \mathrm{mph}$ with gusts up to $145 \mathrm{mph}$. Hugo posed no immediate threat to the U.S. mainland, but was in an extremely dangerous position for islands in the Caribbean Sea.

Hugo and tropical storm Iris are shown at 9 a.m. on September 19 in Figure 3. Although both storms covered similar areas, Hugo was more intense with sustained winds of $105 \mathrm{mph}$ (compared to less than $75 \mathrm{mph}$ for Iris). Hugo continued to track northwestward and strengthened considerably after Iris dissipated. Figures 4 through 8 show the progression of Hugo during landfall. Note how the eye remained intact well inland (Figure 7) before losing its distinction (Figure 8). The eye usually dissipates rapidly after making landfall, but Hugo's eye was observable for over 100 miles.

Figures 9 through 15 show composite radar imagery as Hugo made landfall. The eye is dramatically shown passing over the Charleston area (Figures 9-12) and through the midlands of South Carolina before losing its distinction (Figures 13-15). Also of note is the band of persistent heavy showers over north central Georgia which produced copious amounts of rain accompanied by gusty winds. The SRS was comparatively less active until a strong band of showers passed through around 4-5 a.m. 
The local SRS mesoscale winds were monitored by nine $200-\mathrm{ft}(60-\mathrm{m})$ instrumented meteorological towers. Figure 16 shows the spatially averaged mean (SAM) wind speeds for each 15 minute period from $18 \mathrm{Z}$ (2 p.m.) on Septamber 20 to $18 \mathrm{Z}$ (2 p.m.) on September 23. Increasing wind speeds were observed from 21 Z (5 p.m.) on September 21 until 9 Z (5 a.m.) on September 22, which is when a peak average of $33.1 \mathrm{mph}(14.8 \mathrm{~m} / \mathrm{s})$ occurred. At approximately $9 \mathrm{Z}$ (5 a.m.), Tower $\mathrm{C}$ exhibited the highest average and gust, $38.3 \mathrm{mph}(17.1 \mathrm{~m} / \mathrm{s})$ and $64.9 \mathrm{mph}$ $(29.0 \mathrm{~m} / \mathrm{s})$, respectively (Figures 17 and 18). The spatially averaged wind direction (Figure 19) exhibited a backing behavior (decreasing in degree measure) between 21 Z (5 p.m.) on Sepember 21 and $9 \mathrm{Z}$ (5 a.m.) on the following day. The standard deviation of wind elevation angles (Figure 20) showed an increase from +4 to +9 degrees between $21 \mathrm{Z}$ ( 5 p.m). on September 21 until 0:15 $\mathrm{Z}$ (8:15 p.m.). Values generally remained near +9 degrees until Hugo had passed.

A barometric pressure trace from Building 773-A is shown in Figure 21. The lowest pressure recorded was $986 \mathrm{mb}$ (Note: This is an absolute pressure reading which has not been reduced to sea level pressure.)

Rainfall amounts varied considerably and are shown in Table 5. The maximum observed accumulation was 5.05 inches at $700-\mathrm{A}$ and the minimum was 2.28 inches at Barricade 5 .

Table 5. Total Rainfall Amounts During Hurricane Hugo (inches).

$\begin{array}{ll}\text { 773-A } & 3.55 \\ \text { Barricade 5 } & 2.28 \\ \text { 400-D } & 4.58 \\ 700-A & 5.05 \\ \text { 200-F } & 4.50 \\ \text { 100-P } & 4.63 \\ \text { Barricade 3 } & 2.70 \\ \text { Barricade 2 } & 3.48\end{array}$

\section{POTENTIAL FOR WIND DAMAGE ASSESSMENT FOR SRS}

Table 6 summarizes the likely wind damage from Hugo had the storm passed over SRS. ${ }^{3}$ The wind speed range that was used (80-100 mph) nearly matched the $109 \mathrm{mph}$ wind gust recorded at Shaw AFB, which is approximately the same distance from the Atlantic Ocean as SRS. 
Table 6. Potential Wind Damage Assessment from Hugo

Building Wind Speed Range

80-100 mph

703-A (main administration)

roof gravel loosened

773-A (labs)

no damage

772-F (all isotopes)

roof gravel loosened

234-H (holding tank)

roof gravel loosened

$105-\mathrm{K}$ (reactor)

no damage (filters safe up to $150 \mathrm{mph}$ )

Trailers

evacuation at $40 \mathrm{mph}$ sustained wind

Construction Equipment

securing and proper storing $24 \mathrm{hrs}$ before high wind event

\section{REFERENCES}

1. Case, B. "Hurricanes: Strong Storms Out of Africa," Weatherwise. 43 (1) Hildref Publications Washington, DC (1990:).

2. Simpson, R. H. and Riehl, H. The Hurricane and Its Impact. Louisiana State University Press, Baton Rouge, LA (1981).

3. McDonald, J. R. Assessment of Tornado and Straight Wind Risks at the Savannah River Plant Site in Aiken, South Carolina. Purchase Order No. 7257809, University of California, Lawrence Livermore National Laboratory (1982).

4. Miller, J. F. Two-to-Ten Day Precipitation for Return Periods of Two-to-One Hundred Years in the Contiguous United States. Technical Paper No. 49, U.S. Weather Bureau, U.S. Department of Commerce (1964).

5. Fujita, T. T., Tornado and High Wind Hazards. Purchase ORder No. 7249609, University of California, Lawrence Livermore National Laboratory (1980). 


\section{APPENDIX A}

Saffir/Simpson Damage-Potential Scale

\section{Category 1}

- winds $74-95 \mathrm{mph}$

- damage primarily to shrubbery, trees, foliage, and unanchored mobile homes

- no real damage to other structures

- some damage to poorly constructed signs

- storm surge 4-5 feet above normal

- low-lying coastal roads inundated

- minor pier damage

- some small craft torn from moorings in exposed anchorage

\section{Category 2}

- winds $96-110 \mathrm{mph}$

- considerable damage to exposed mobile homes

- extensive damage to poorly constructed signs

- some damage to roofing materials of buildings

- some window and dnor damage

- no major damage to buildings

- storm surge 6-8 feet above normal

- coastal roads and low-lying escape routes inland cut by rising water 2 to 4 hours before arrival of hurricane center

- considerable damage to piers

- small craft torn from moorings in unprotected anchorages

- evacuation of some shoreline residences and low-lying island areas required

\section{Category 3}

- winds $111-130 \mathrm{mph}$

- foliage torn from trees

- large trees blown down

- practically all poorly constructed signs blown down

- some damage to roofing materials of buildings

- some window and door damage

- some structural damage to small buildings

- mobile homes destroyed

- storm surge 9-12 feet above normal

- serious flooding at coast

- many smaller structures near coast destroyed

- larger structures near coast damaged by battering waves and floating debris

- low-lying escape routes cut by rising water 3-5 hours before hurricane center arrives

- flat terrain five feet or less above sea level flooded inland eight miles or more

- evacuation of low-lying residences within several blocks of shoreline possibly required 


\section{Category 4}

- winds $131-155 \mathrm{mph}$

- shrubs and trees blown down

- all signs down

- extensive damage to roofing materials, windows, and doors

- complete failure of roofs on many small residences

- complete destruction of mobile homes

- surge 13-18 feet above sea level flooded inland as far as six miles

- major damage to lower floors of structures near shore due to flooding and battering by waves and floaing debris

- low-lying escape routes inland cut by rising water 3-5 hours before hurricane center arrives

- major erosion of beaches

- massive evacuation of all residences within 500 yards of shore possibly required

- evacuation of single-story residences on low ground within two miles of shore required

\section{Category 5}

- winds greater than $155 \mathrm{mph}$

- shrubs and trees blown down

- considerable damage to roofs or buildings

- all signs down

- very severe and extensive damage to windows and doors

- complete failure of roofs on many residences and industrial buildings

- extensive shattering of glass in windows and doors

- some complete building failures

- small buildings oveiturned or blown away

- complete destruction of mobile homes

- storm surge greater than 18 feet above normal

- major damage to lower floors of all structures less than 15 feet above sea level within 500 yards of shore

- low-lying escape routes inland cut by rising water 3-5 hours before hurricane center arrives

- massive evacuation of residential areas on low ground within 5-10 miles of shore possibly required

\section{Saffir/Simpson Damage-Potential Scale Ranges}

\begin{tabular}{llllll}
$\begin{array}{l}\text { Scale } \\
\text { Number }\end{array}$ & \multicolumn{1}{c}{$\begin{array}{c}\text { Central Pressure } \\
\text { Inches }\end{array}$} & $\begin{array}{l}\text { Winds } \\
(\mathbf{m p h})\end{array}$ & $\begin{array}{l}\text { Surge } \\
(\mathbf{f e e t})\end{array}$ & Damage \\
\hline 1 & 2980 & $\geq 28.94$ & $74-95$ & $4-5$ & Minimal \\
2 & $965-979$ & $28.50-28.91$ & $96-110$ & $6-8$ & Moderate \\
3 & $945-964$ & $27.91-28.47$ & $111-130$ & $9-12$ & Extensive \\
4 & $920-944$ & $27.17-27.88$ & $131-155$ & $13-18$ & Extreme \\
5 & $<920$ & $<27.17$ & $>155$ & $>18$ & Datastrophic
\end{tabular}




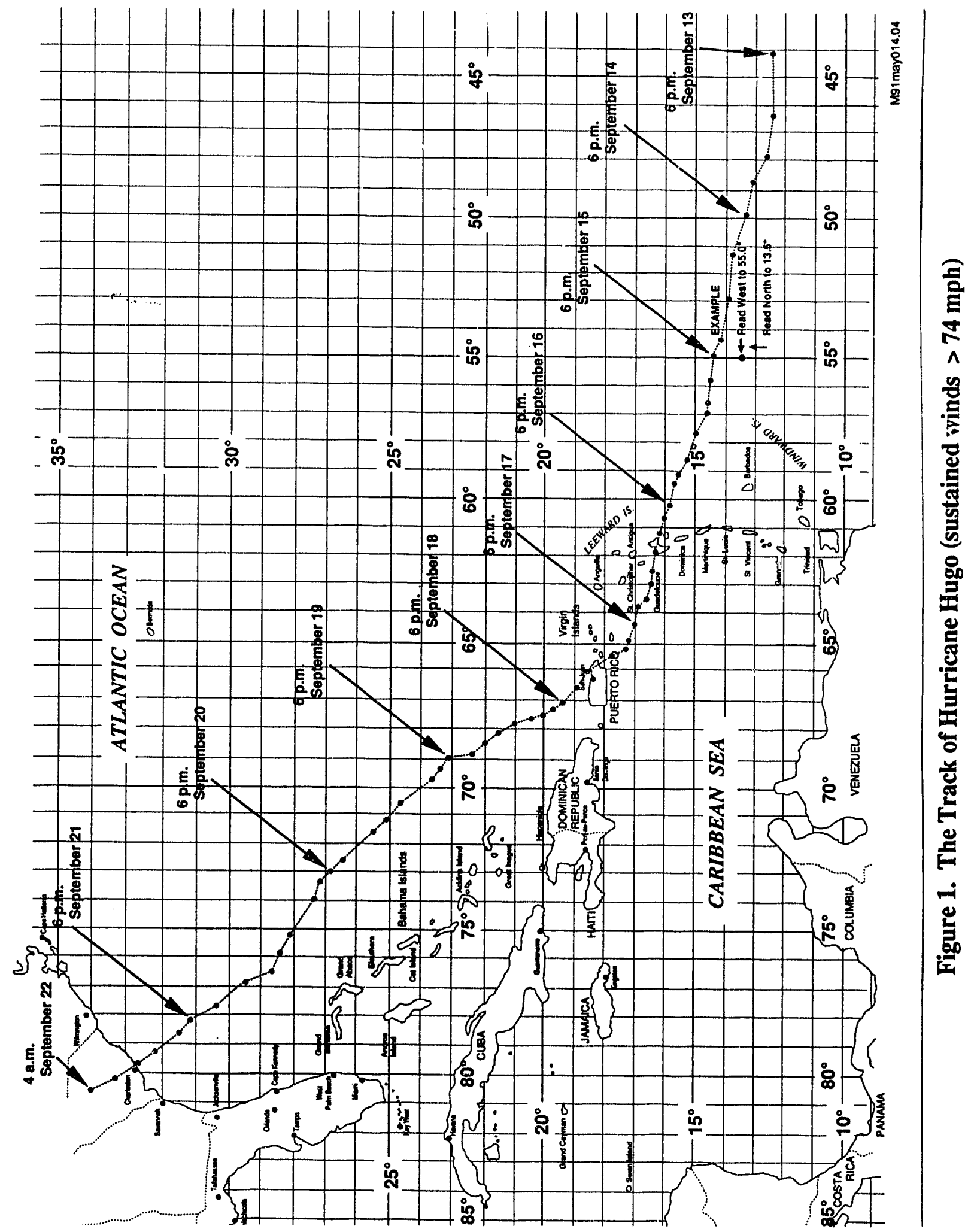




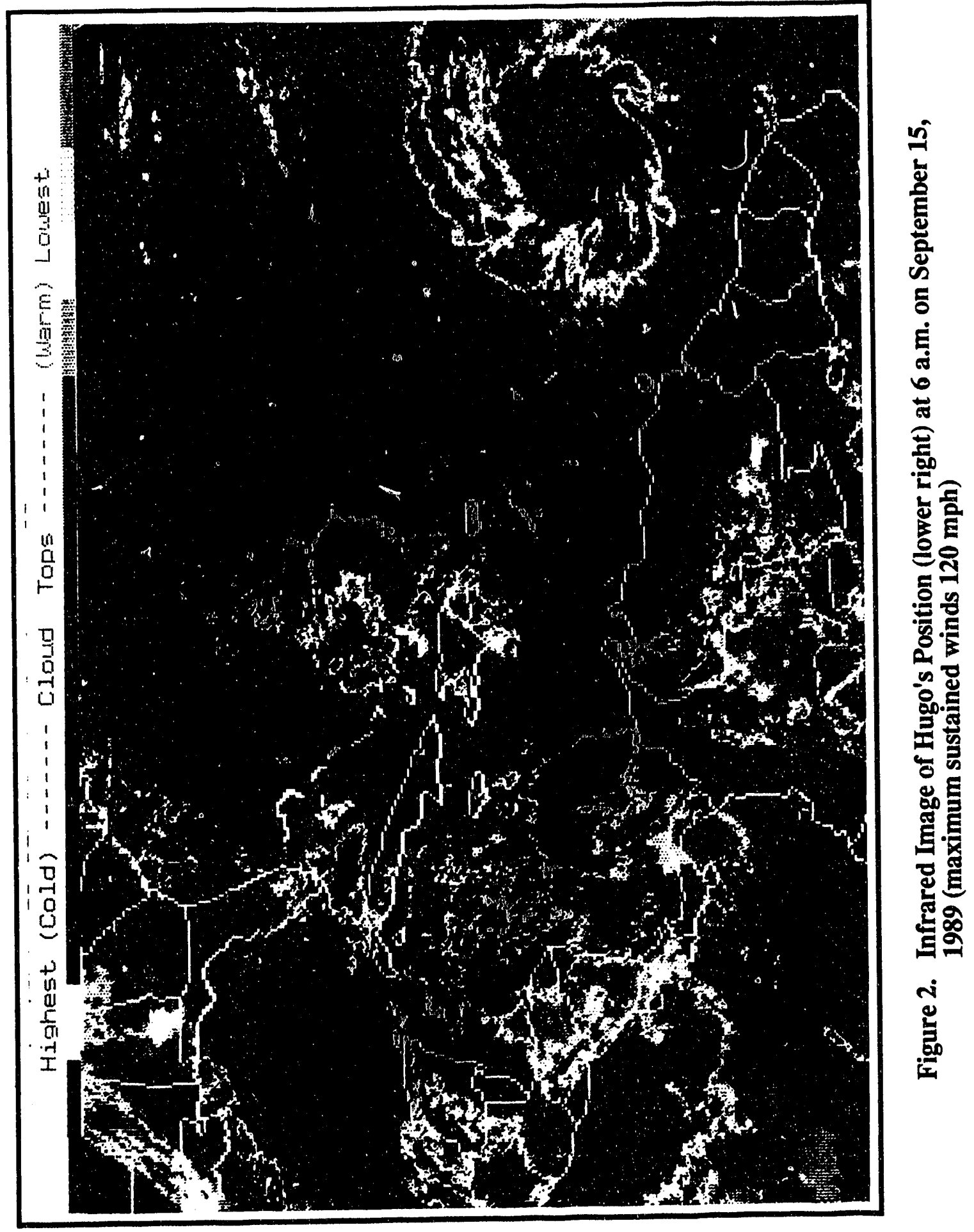




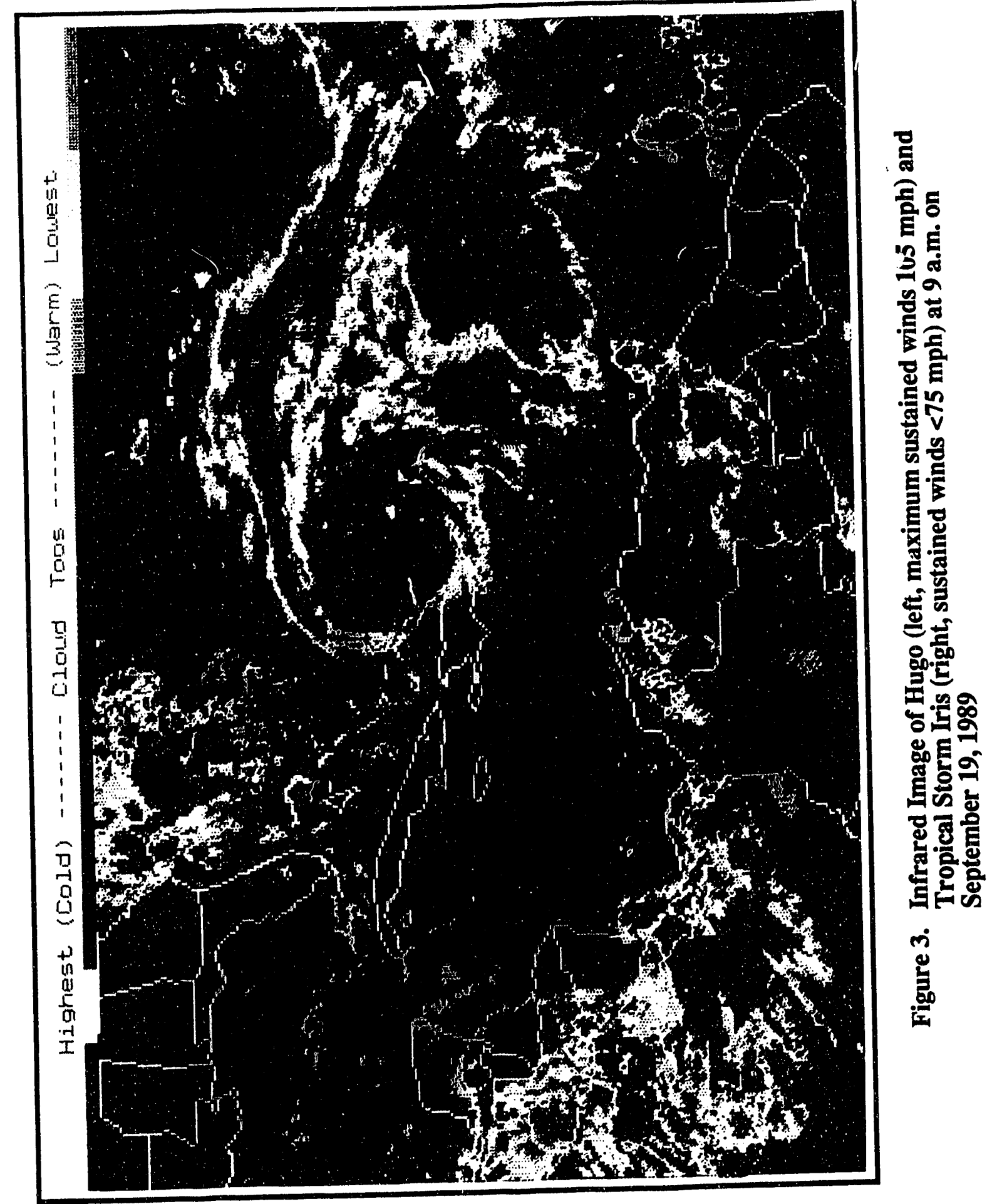




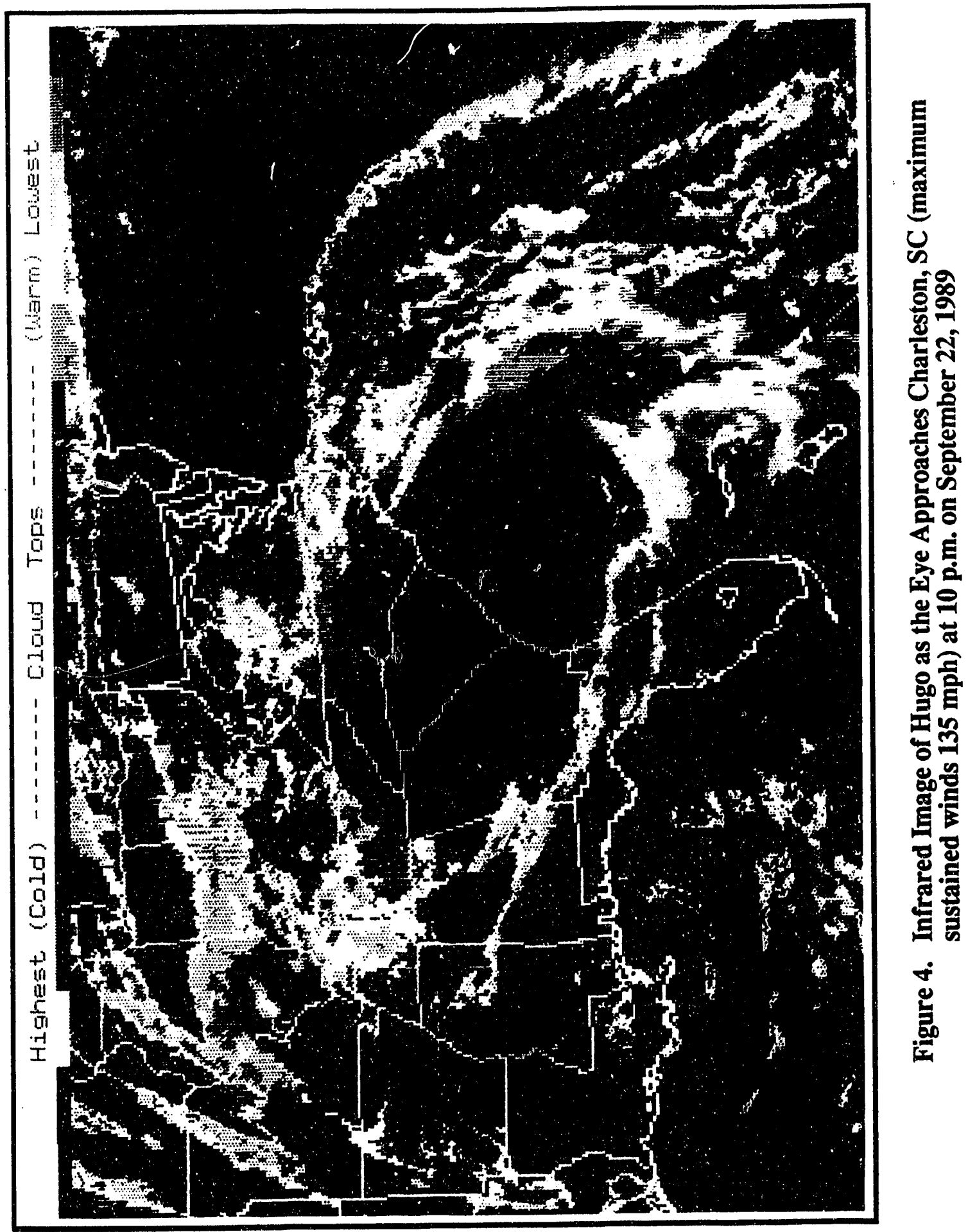




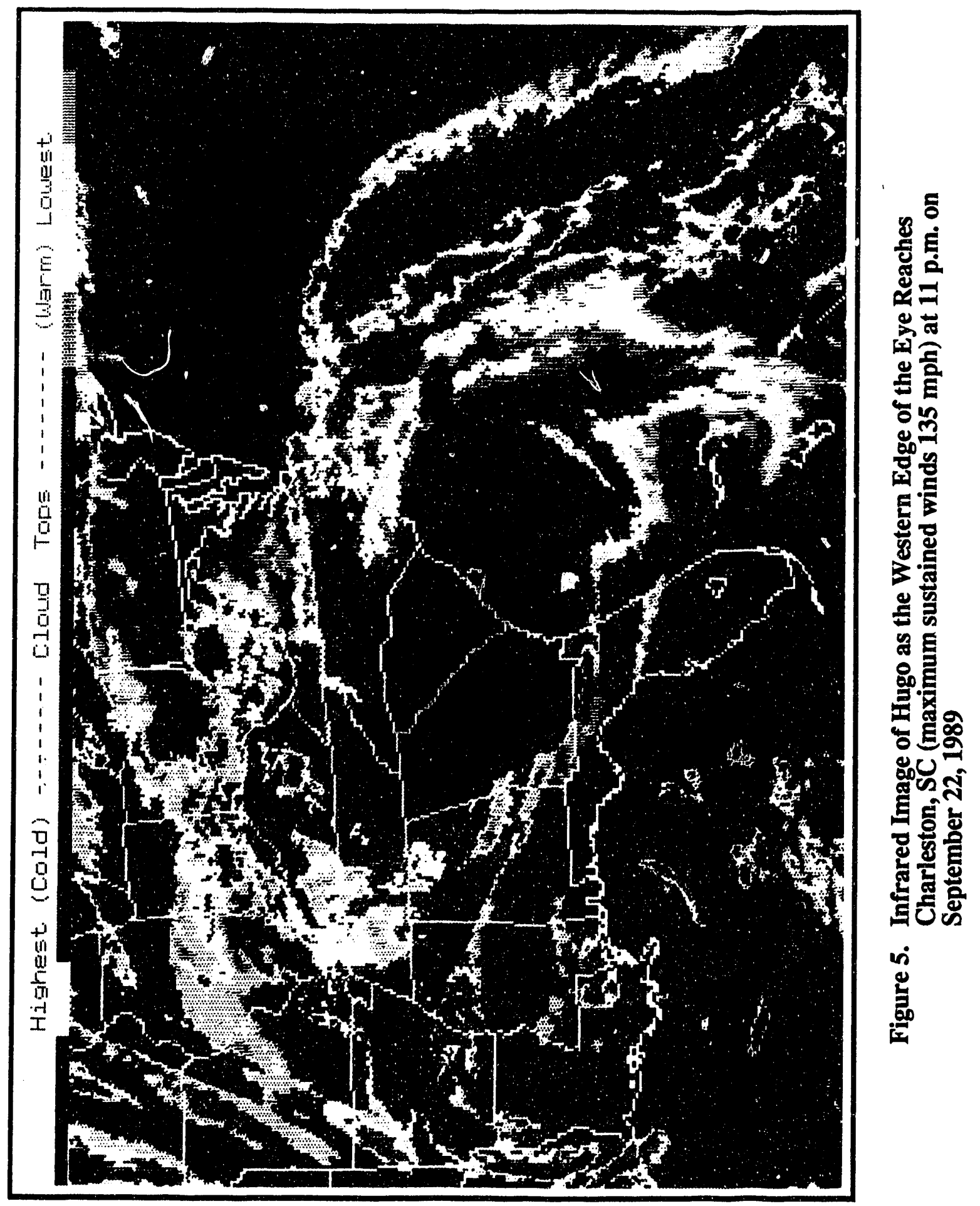




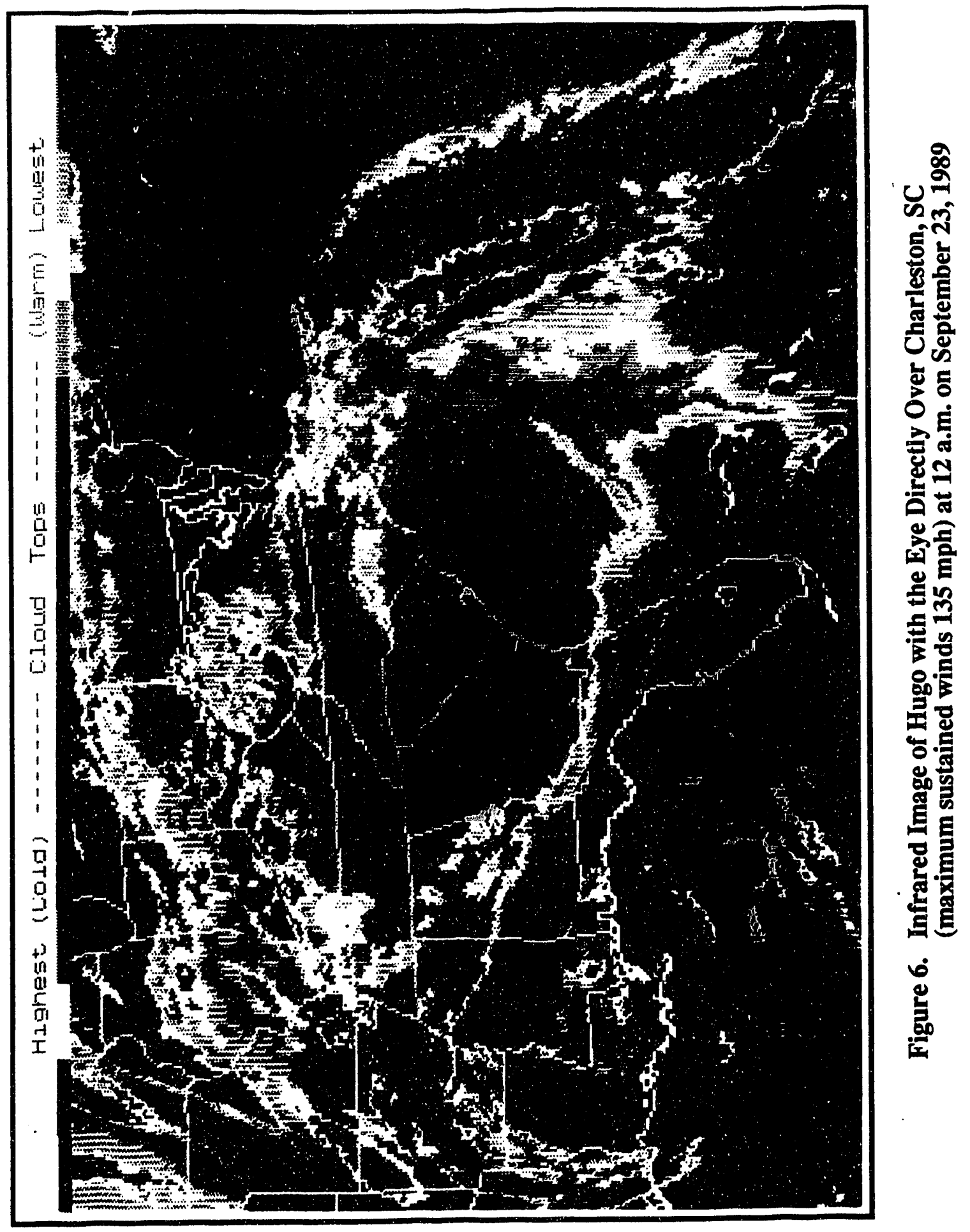




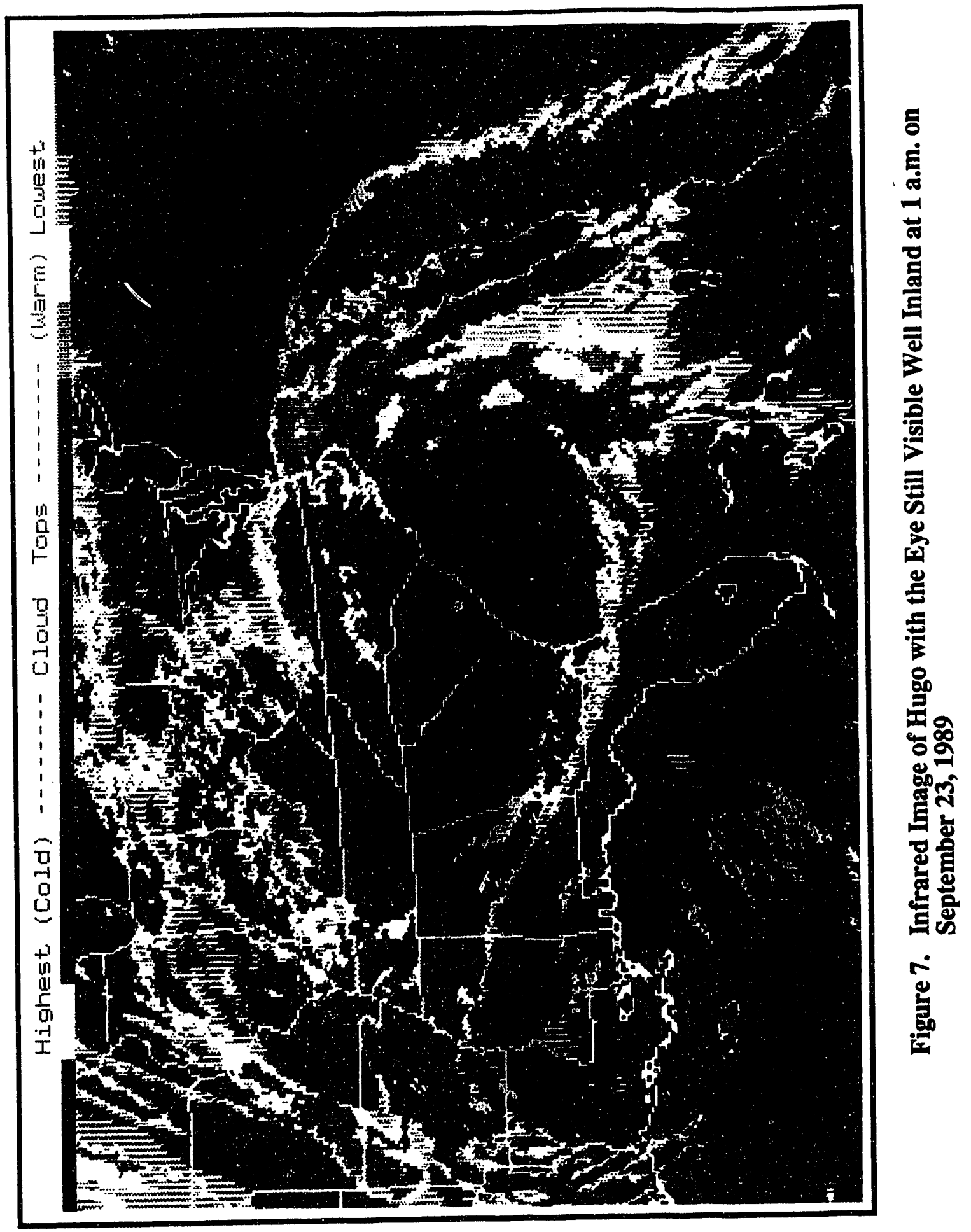




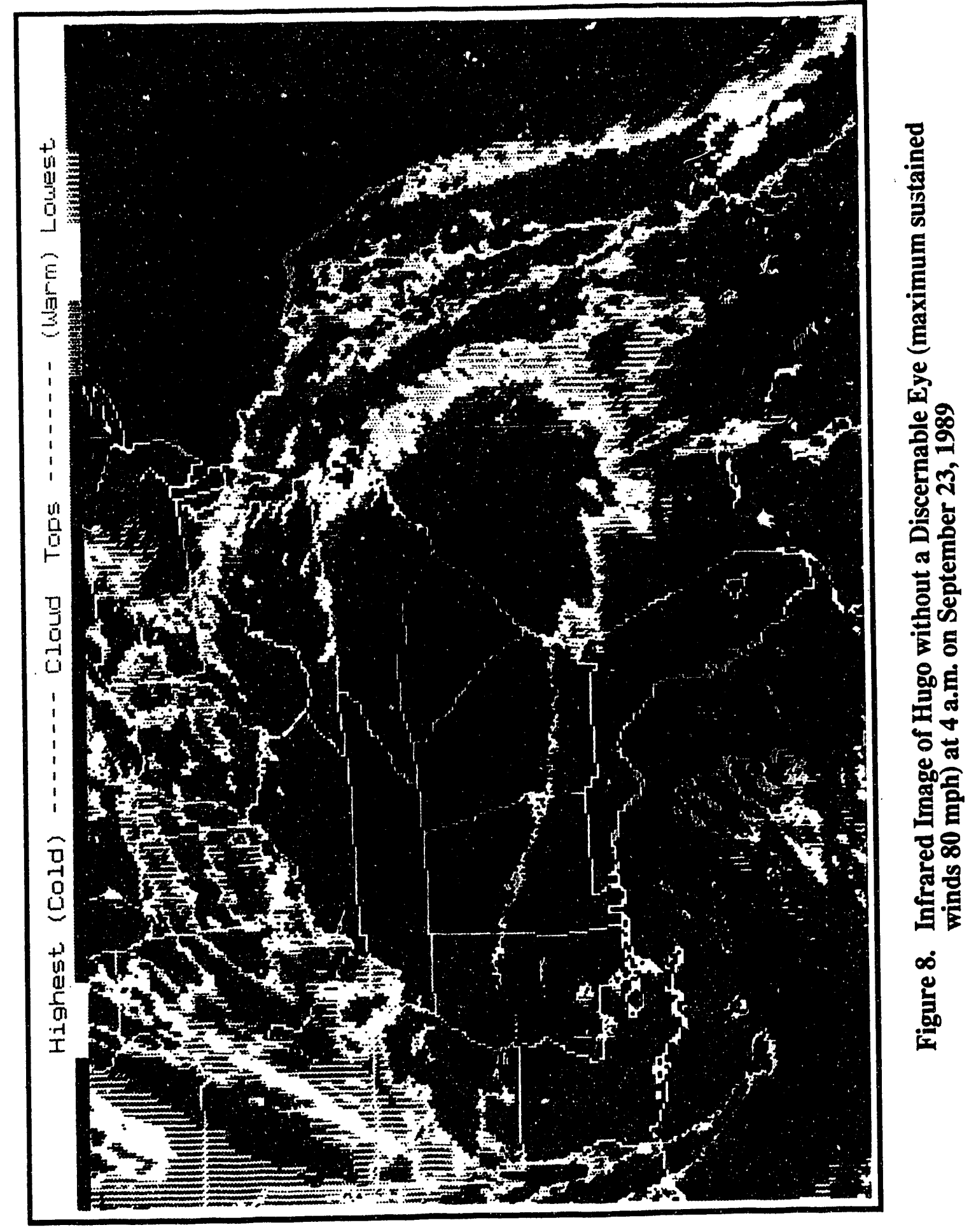




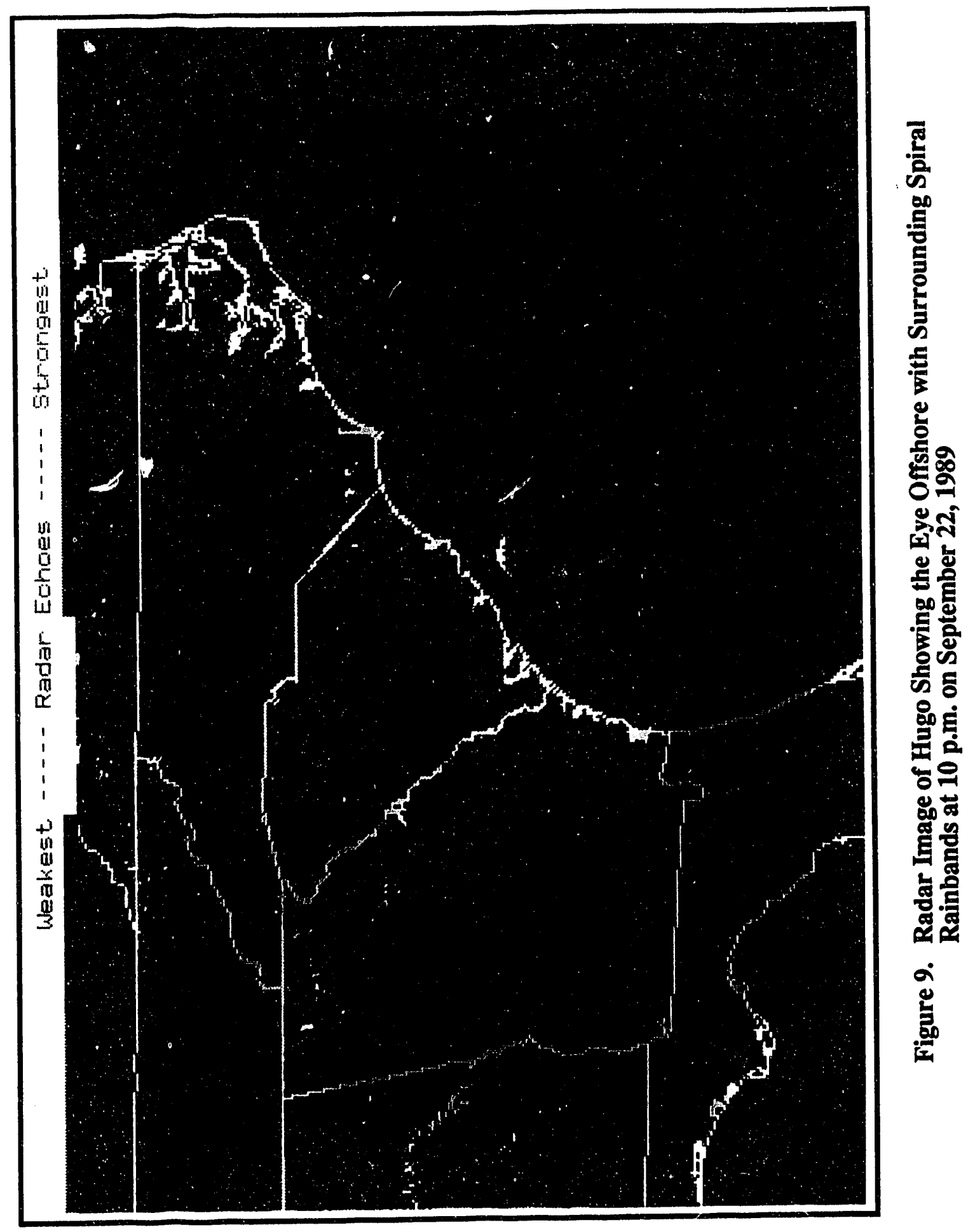




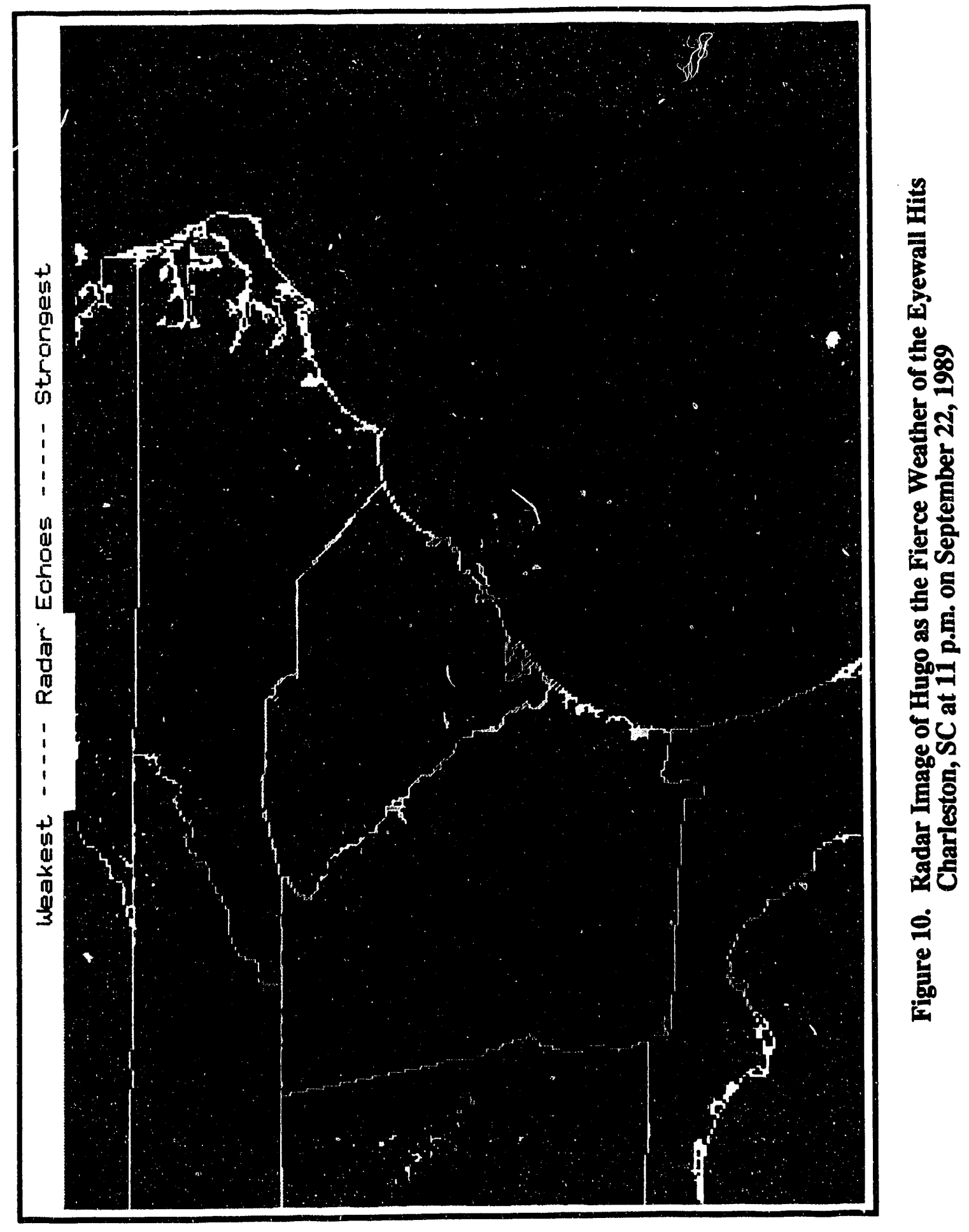




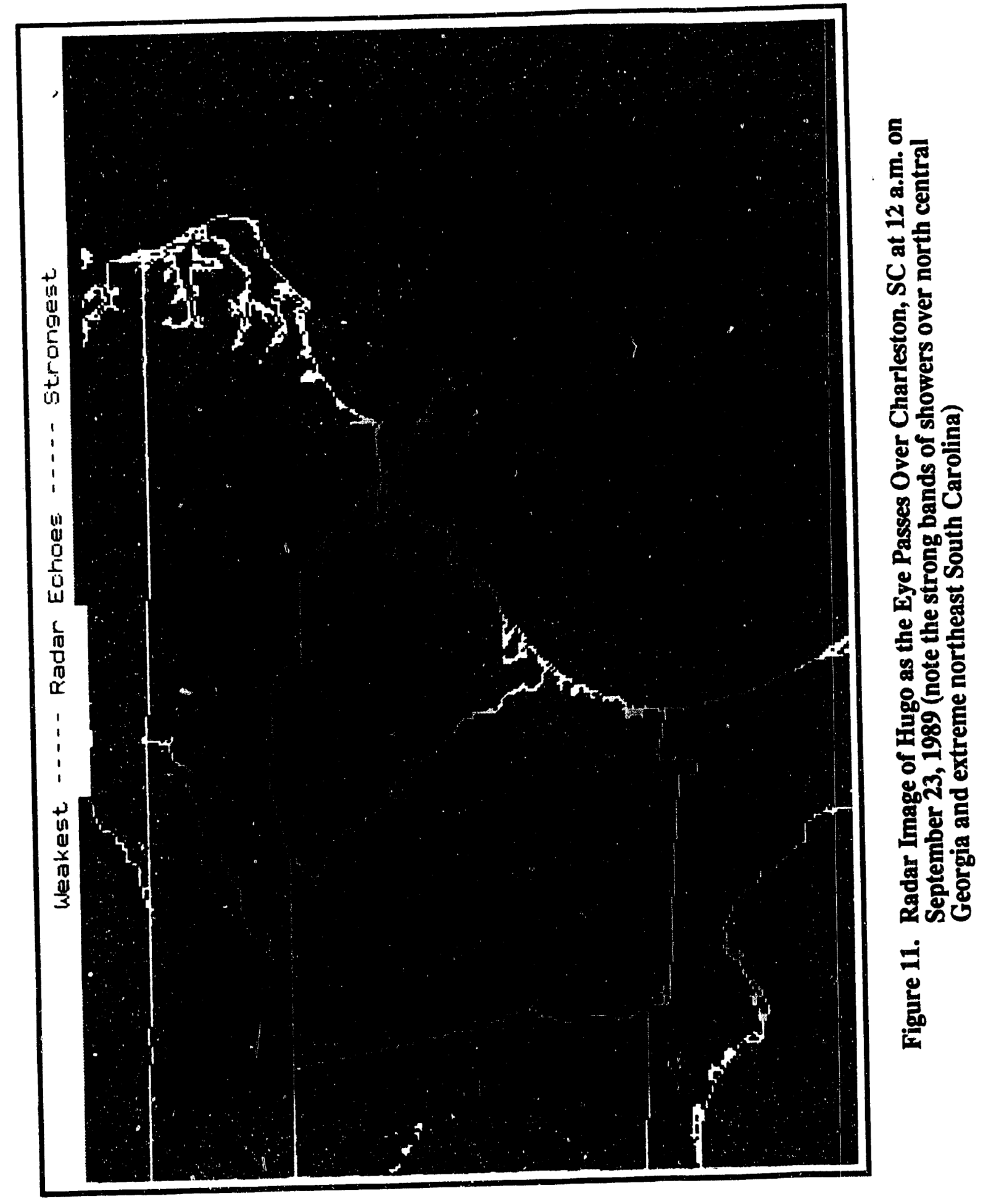




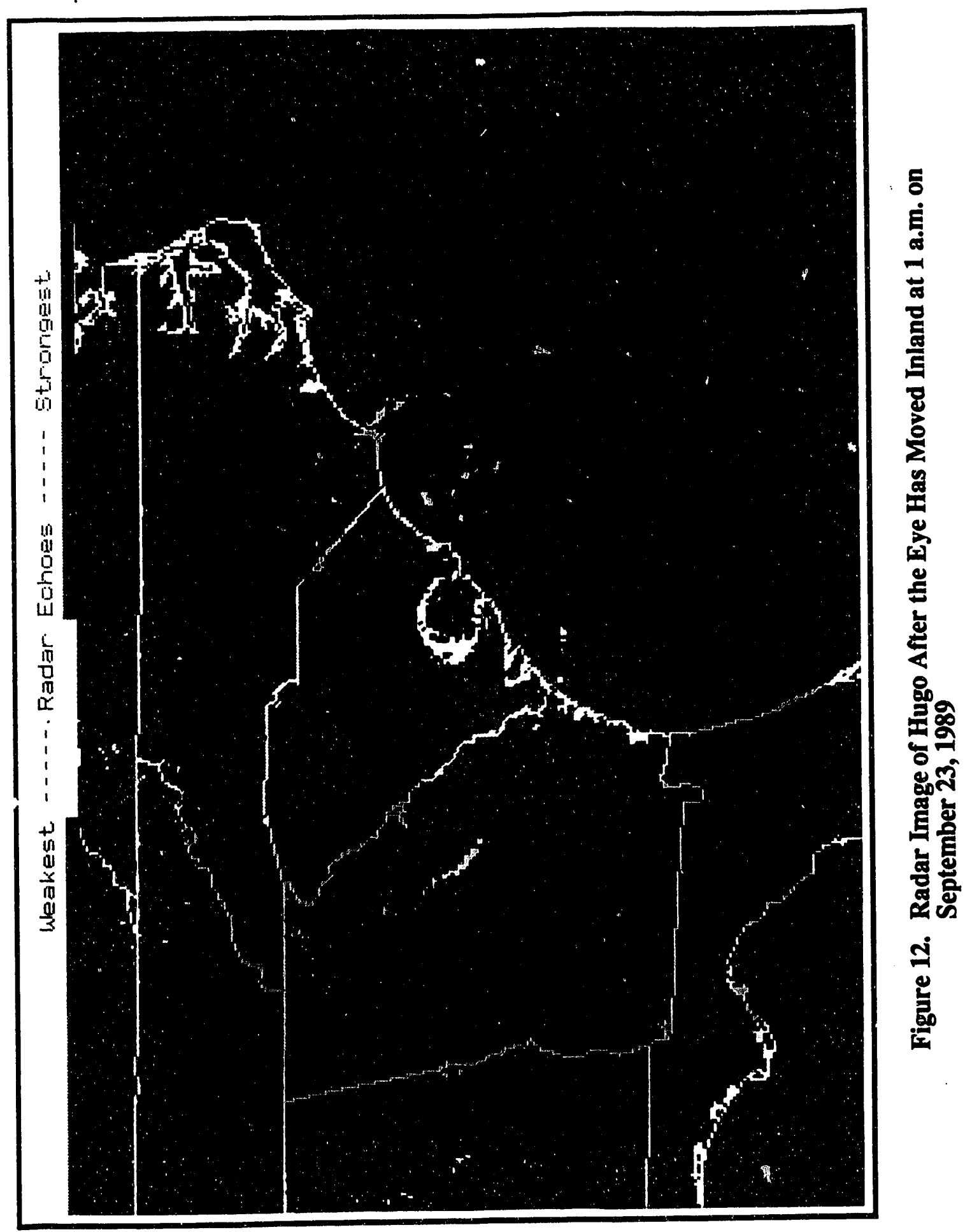




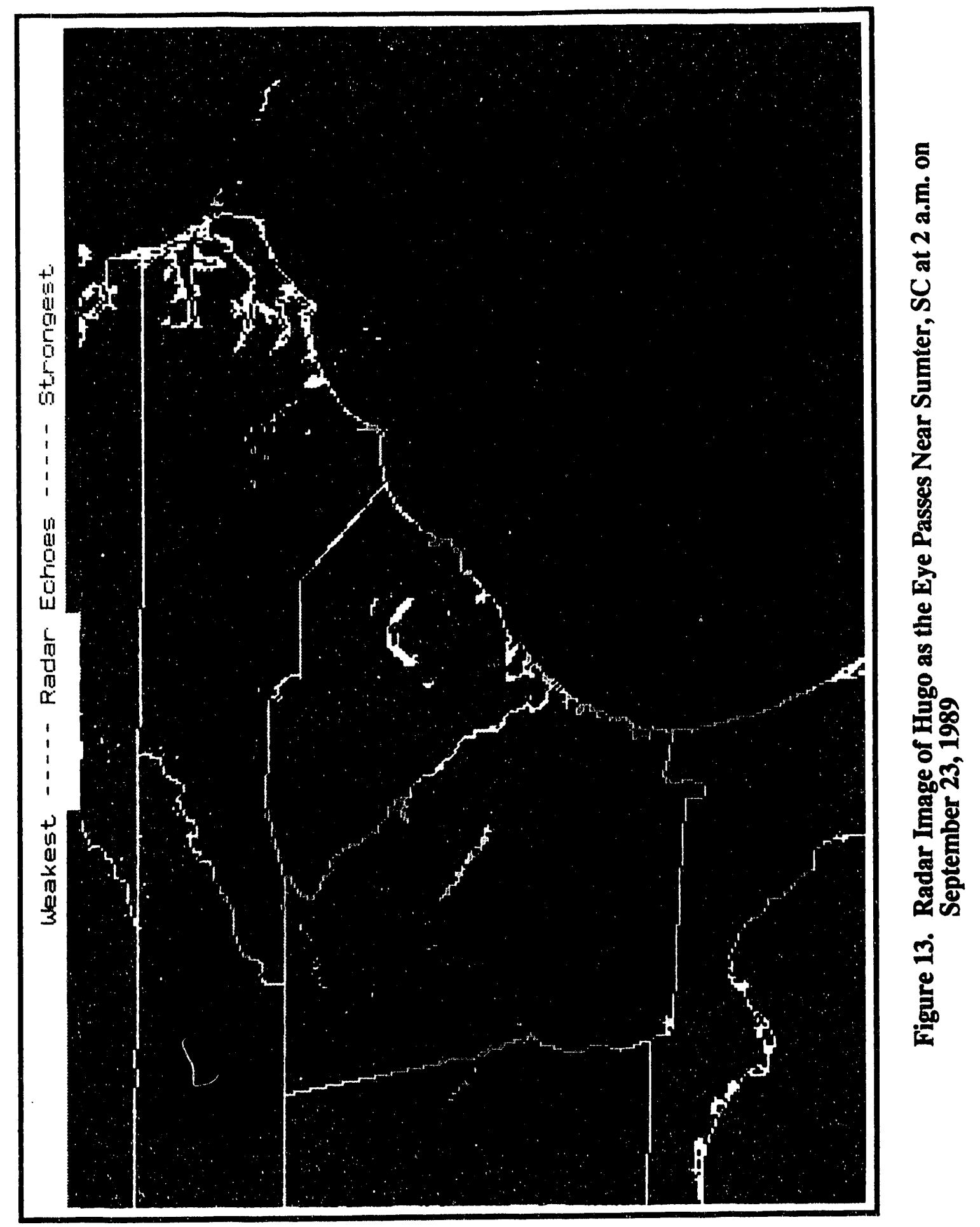




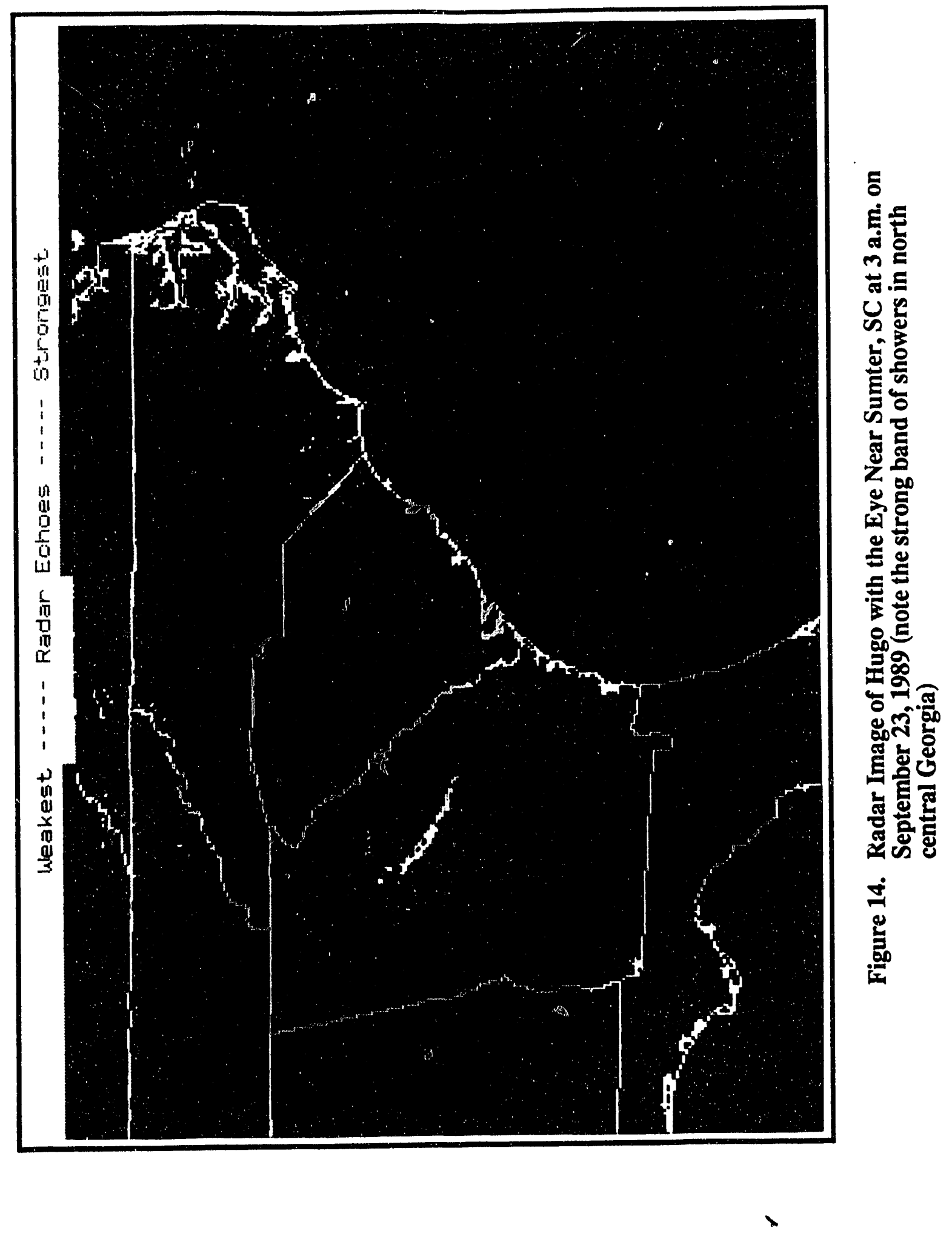




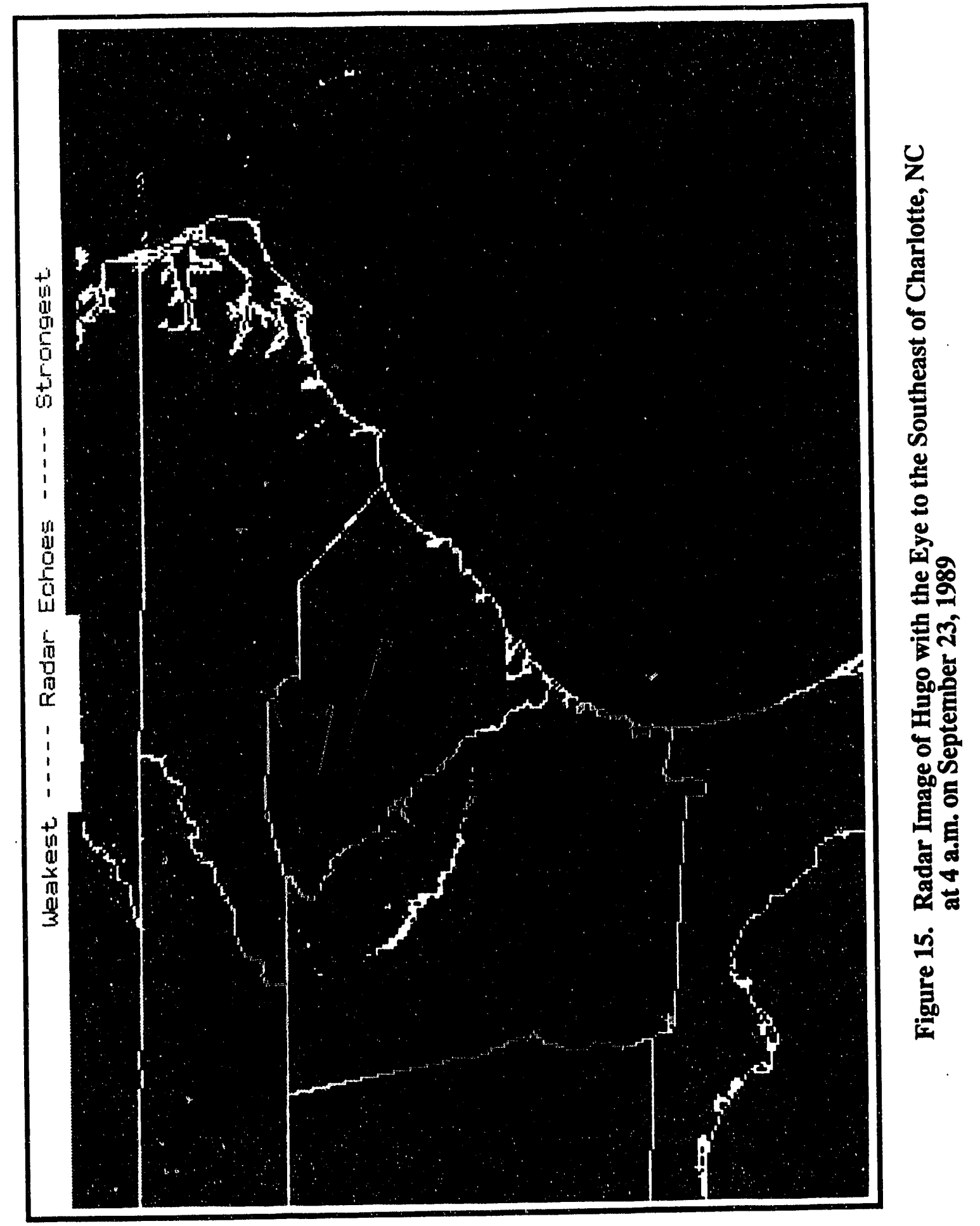




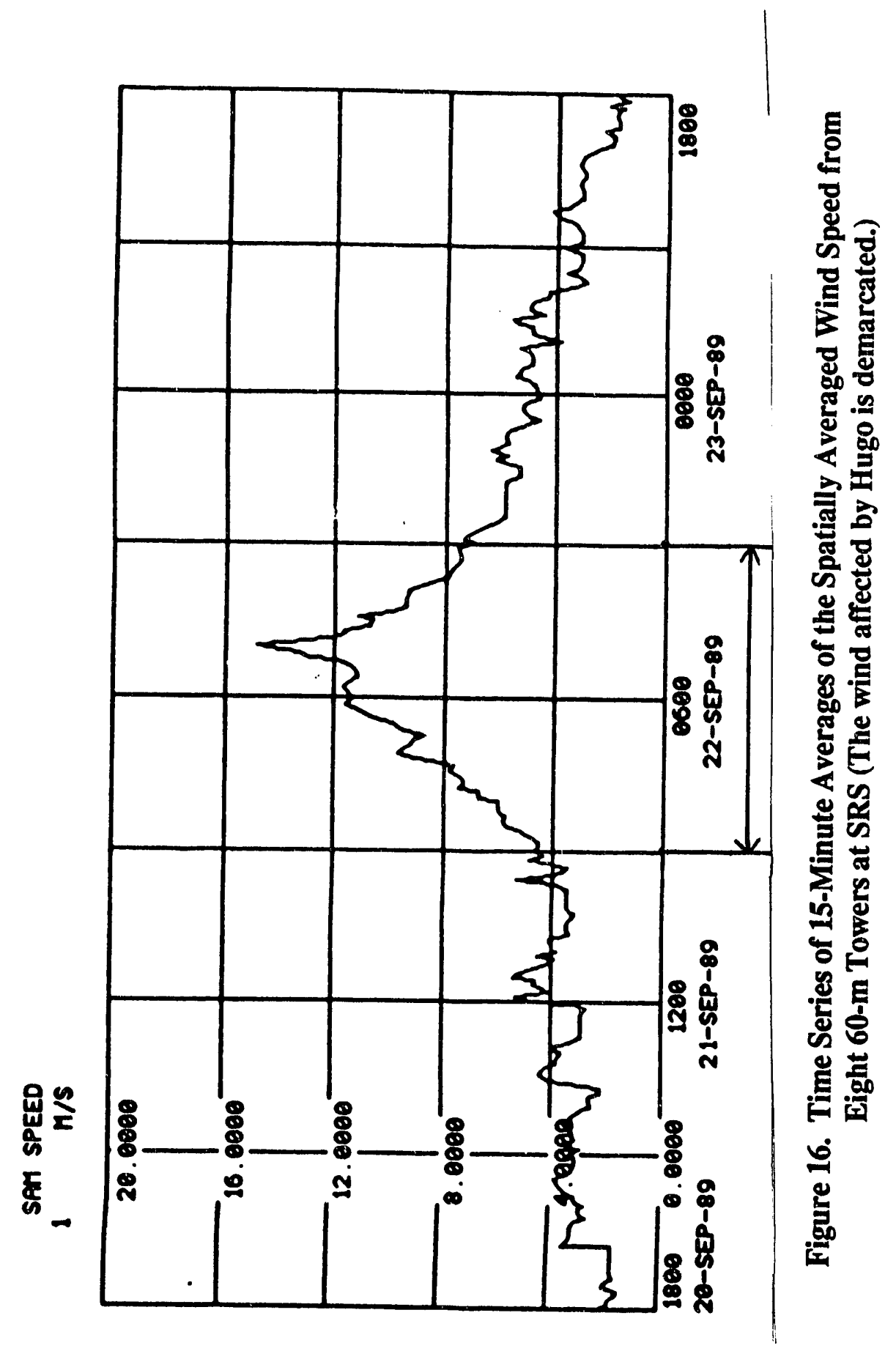




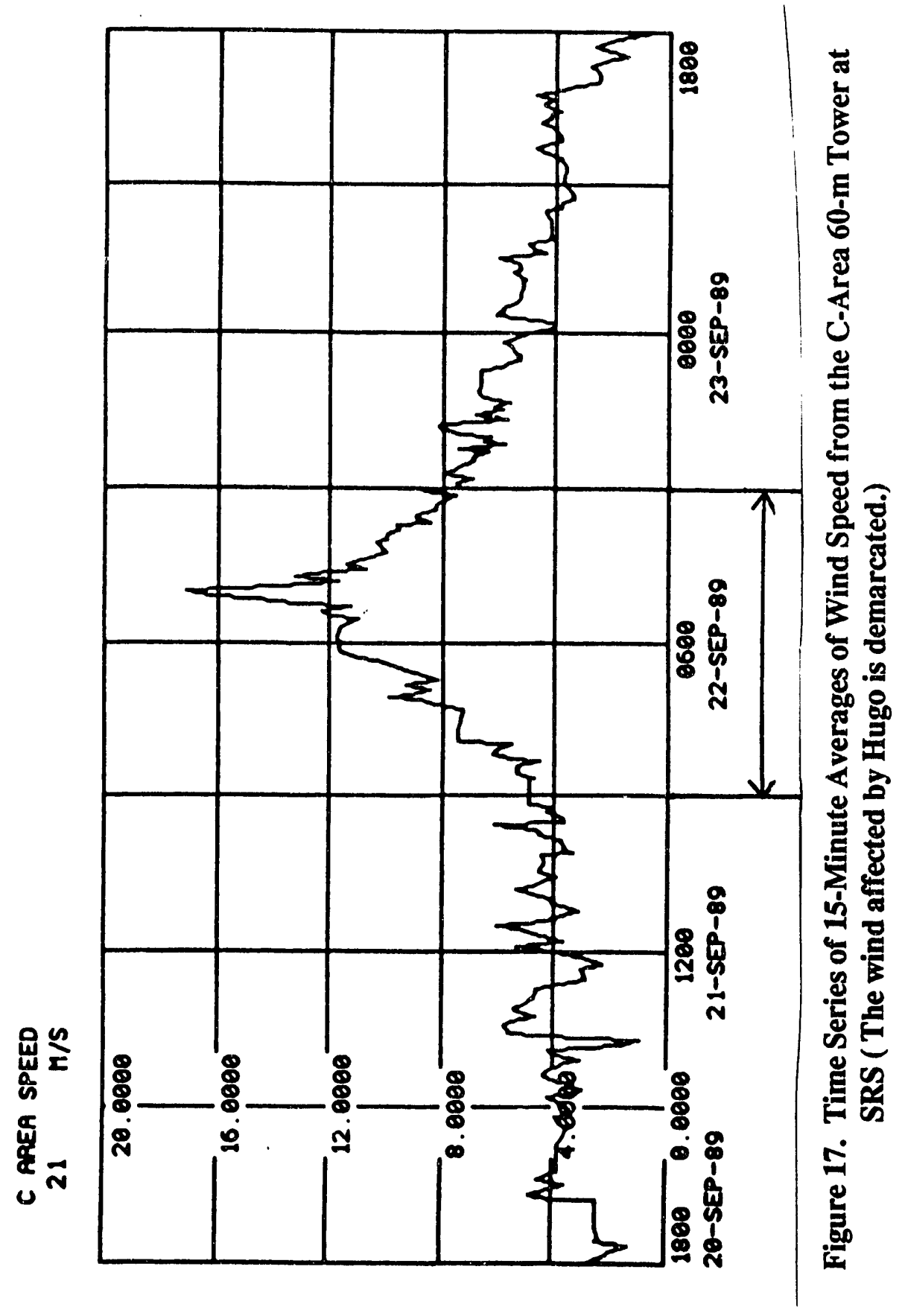




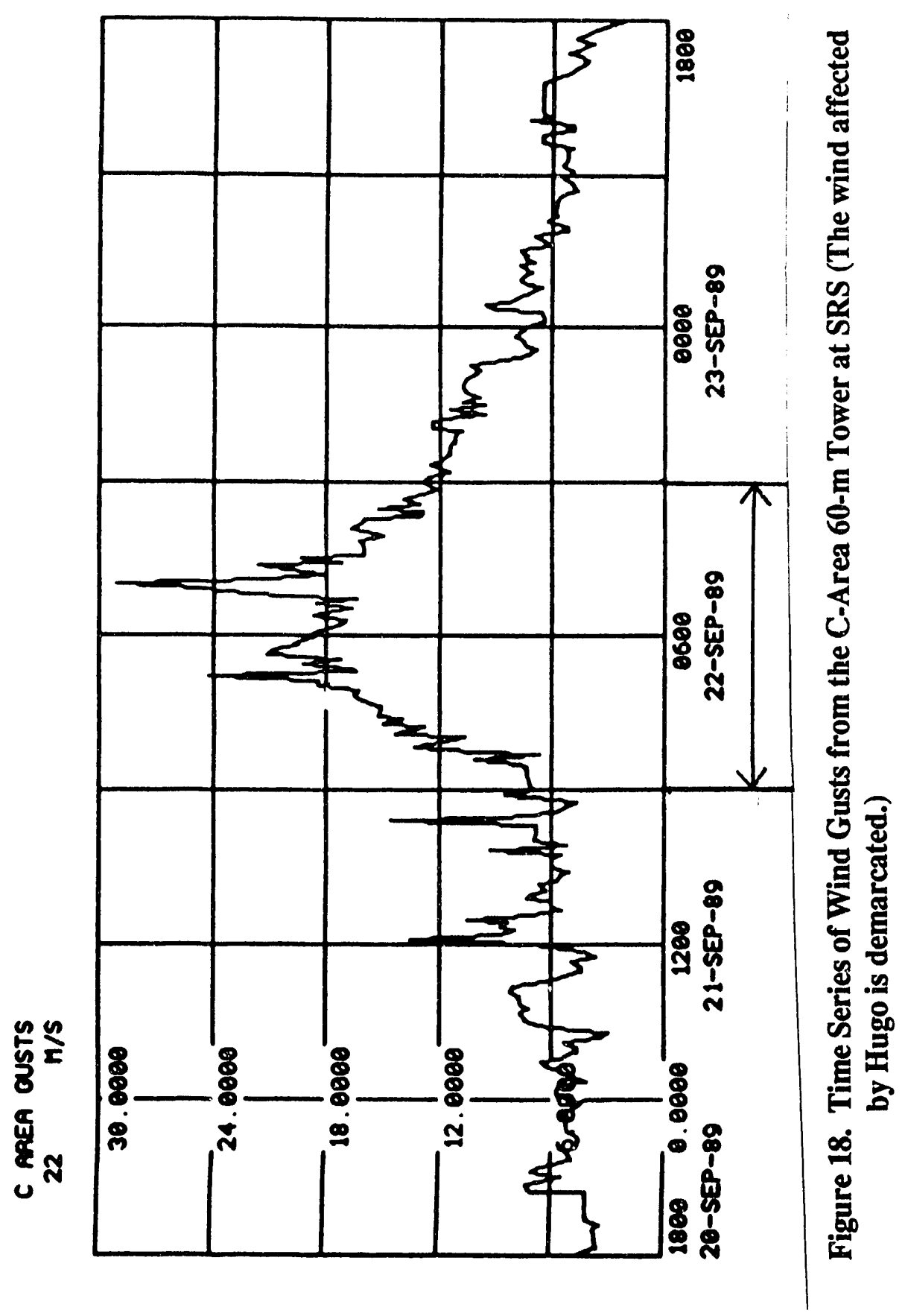




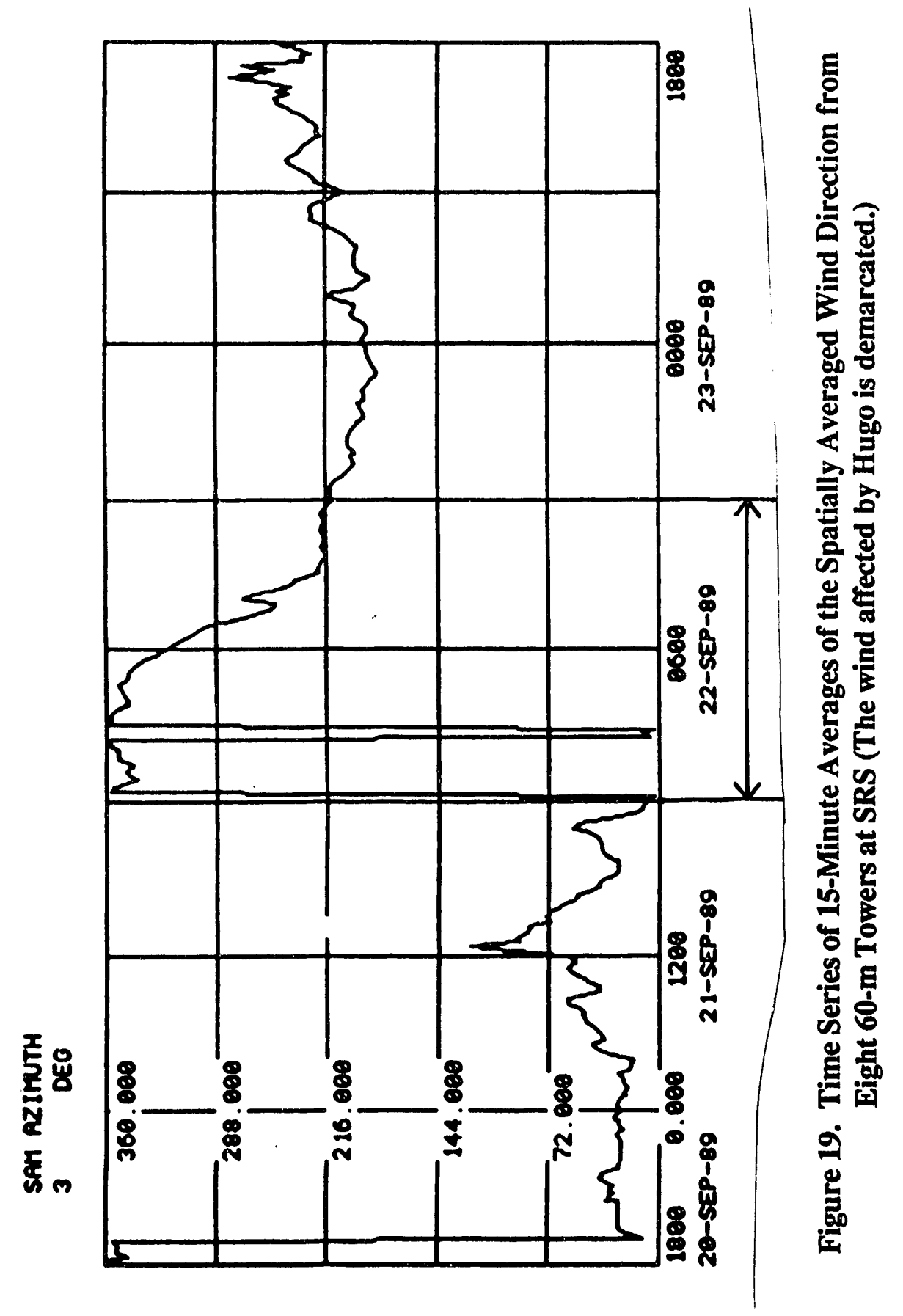




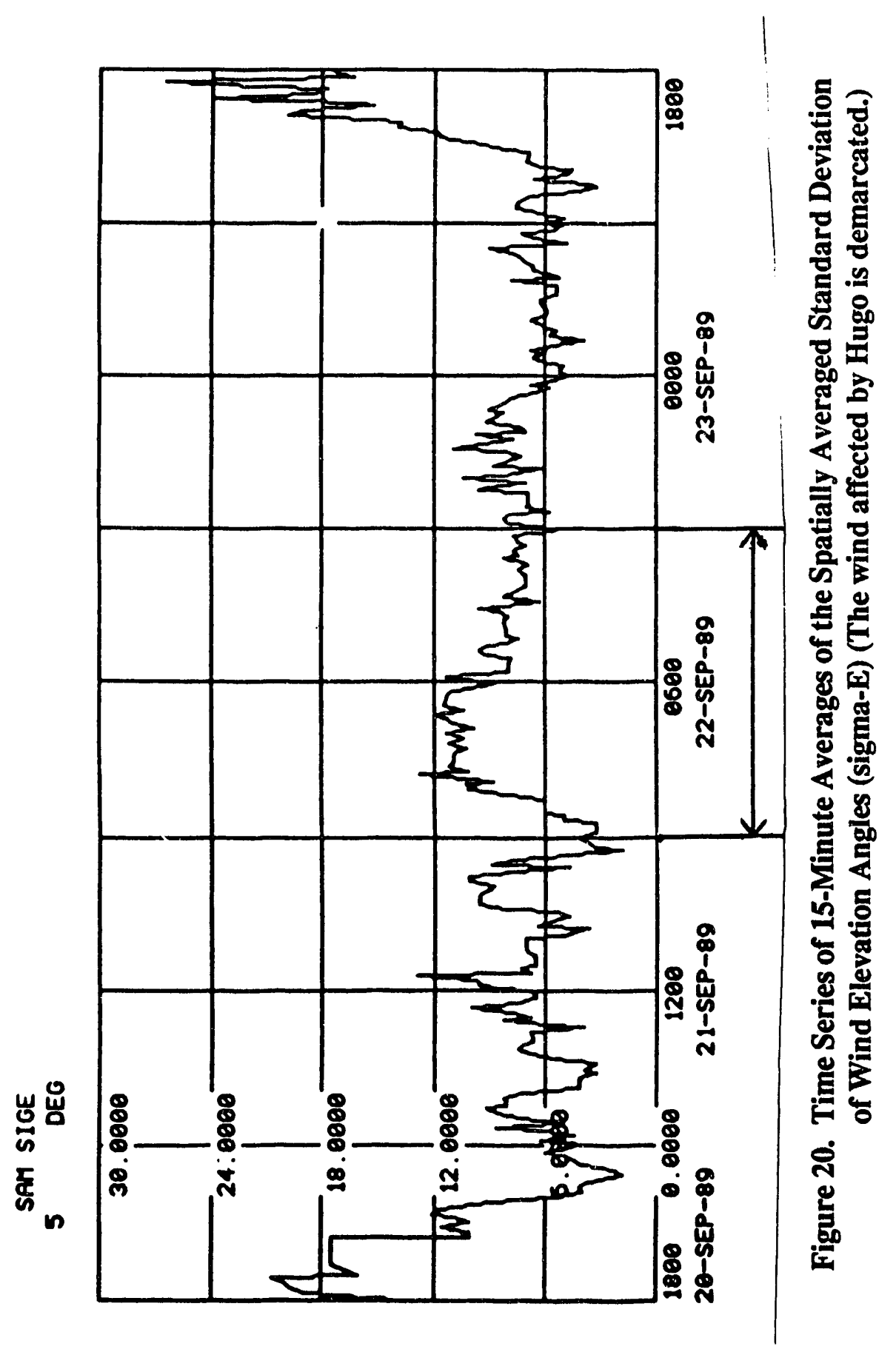




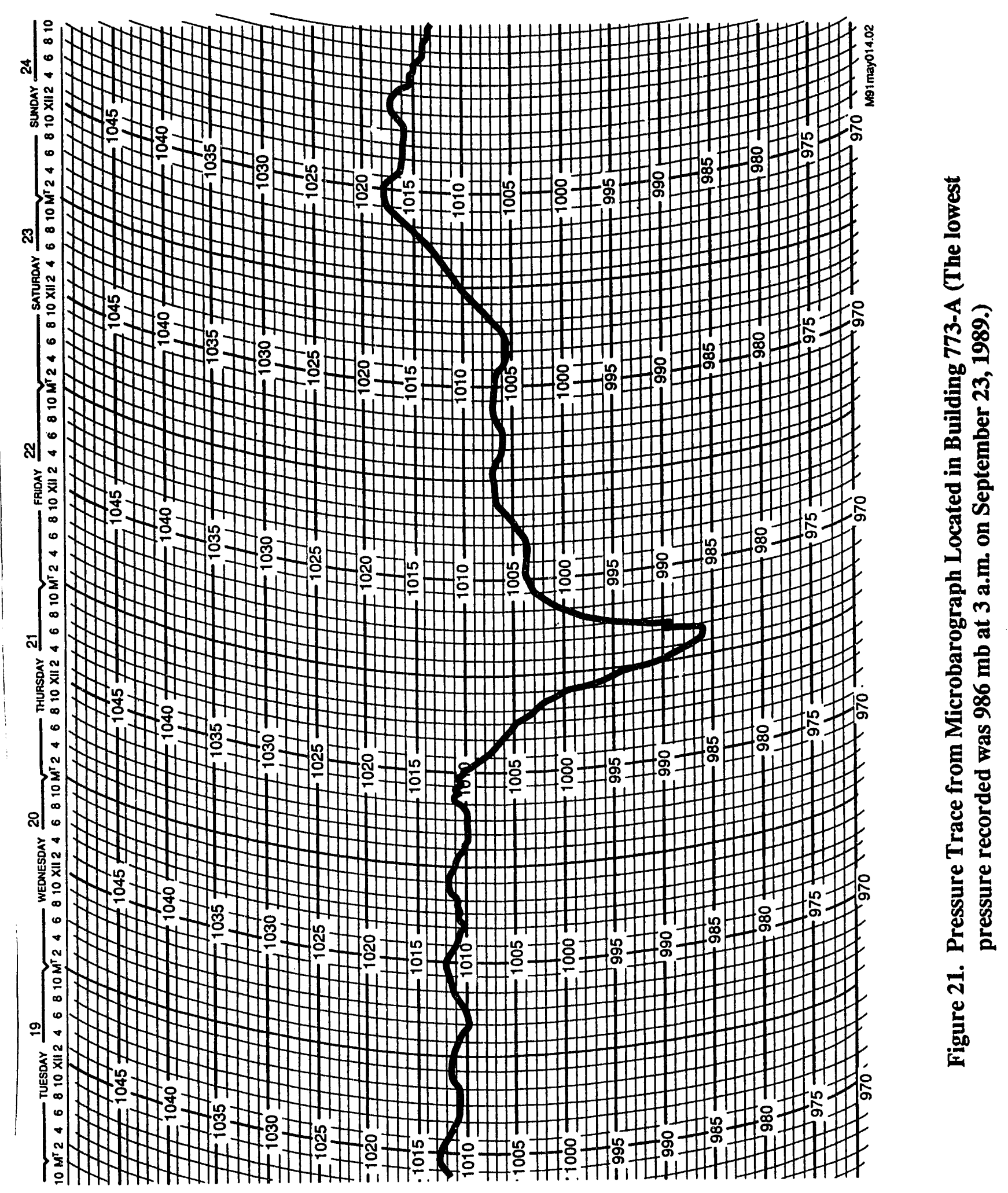




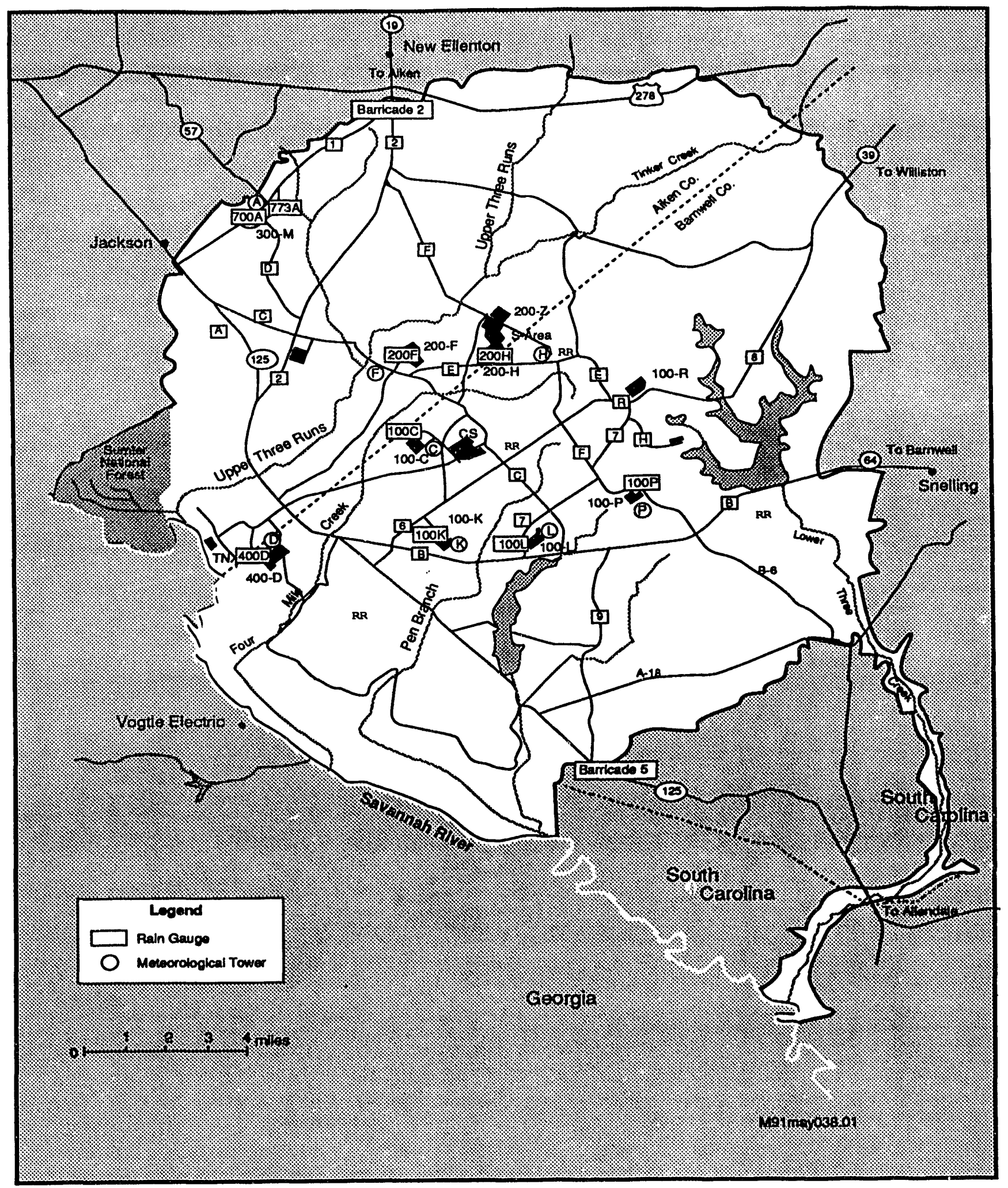

Figure 22. Location of Meteorological Towers and Rain Gauges at SRS 

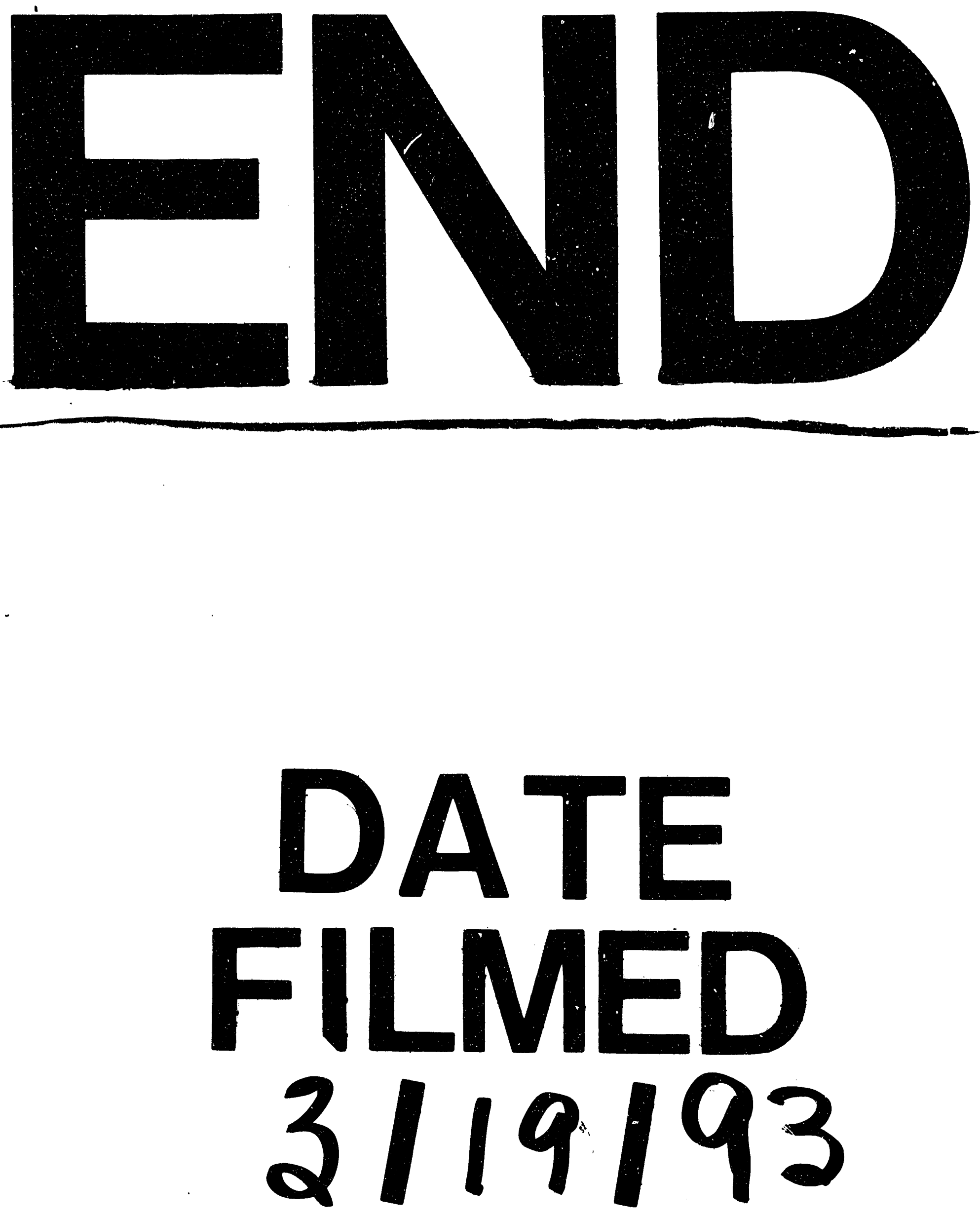